\title{
Rates and risk factors for preterm birth and low birthweight in the global network sites in six low- and low middle-income countries
}

\author{
Yamini V. Pusdekar ${ }^{1 *}+\left(\mathbb{0}\right.$, Archana B. Patel ${ }^{1,2 \dagger}$, Kunal G. Kurhe', Savita R. Bhargav ${ }^{1}$, Vanessa Thorsten ${ }^{3}$, \\ Ana Garces ${ }^{4}$, Robert L. Goldenberg ${ }^{5}$, Shivaprasad S. Goudar ${ }^{6}$, Sarah Saleem7, Fabian Esamai ${ }^{8}$, Elwyn Chomba ${ }^{9}$, \\ Melissa Bauserman ${ }^{10}$, Carl L. Bose $^{10}$, Edward A. Liechty ${ }^{11}$, Nancy F. Krebs ${ }^{12}$, Richard J. Derman ${ }^{13}$, \\ Waldemar A. Carlo ${ }^{14}$, Marion Koso-Thomas ${ }^{15}$, Tracy L. Nolen ${ }^{3}$, Elizabeth M. McClure ${ }^{3}$ and Patricia L. Hibberd ${ }^{16}$
}

\begin{abstract}
Background: Preterm birth continues to be a major public health problem contributing to $75 \%$ of the neonatal mortality worldwide. Low birth weight (LBW) is an important but imperfect surrogate for prematurity when accurate assessment of gestational age is not possible. While there is overlap between preterm birth and LBW newborns, those that are both premature and LBW are at the highest risk of adverse neonatal outcomes. Understanding the epidemiology of preterm birth and LBW is important for prevention and improved care for at risk newborns, but in many countries, data are sparse and incomplete.

Methods: We conducted data analyses using the Global Network's (GN) population-based registry of pregnant women and their babies in rural communities in six low- and middle-income countries (Democratic Republic of Congo, Kenya, Zambia, Guatemala, India and Pakistan). We analyzed data from January 2014 to December 2018. Trained study staff enrolled all pregnant women in the study catchment area as early as possible during pregnancy and conducted follow-up visits shortly after delivery and at 42 days after delivery. We analyzed the rates of preterm birth, LBW and the combination of preterm birth and LBW and studied risk factors associated with these outcomes across the GN sites.
\end{abstract}

Results: A total of 272,192 live births were included in the analysis. The overall preterm birth rate was $12.6 \%$ (ranging from $8.6 \%$ in Belagavi, India to $21.8 \%$ in the Pakistani site). The overall LBW rate was $13.6 \%$ (ranging from $2.7 \%$ in the Kenyan site to $21.4 \%$ in the Pakistani site). The overall rate of both preterm birth and LBW was 5.5\% (ranging from 1.2\% in the Kenyan site to $11.0 \%$ in the Pakistani site). Risk factors associated with preterm birth, LBW and the combination were similar across sites and included nulliparity [RR - 1.27 (95\% Cl 1.21-1.33)], maternal age under 20 [RR 1.41 (95\% Cl 1.32-1.49)] years, severe antenatal hemorrhage [RR 5.18 95\% Cl 4.44-6.04)], hypertensive disorders [RR 2.74 (95\% Cl $-1.21-1.33]$, and 1-3 antenatal visits versus four or more [RR 1.68 (95\% Cl 1.55-1.83)].

Conclusions: Preterm birth, LBW and their combination continue to be common public health problems at some of the GN sites, particularly among young, nulliparous women who have received limited antenatal care services.

*Correspondence: dryaminipusdekar27@gmail.com

${ }^{\dagger}$ Yamini V. Pusdekar and Archana B. Patel contributed equally to this work

${ }^{1}$ Lata Medical Research Foundation, Nagpur, India

Full list of author information is available at the end of the article

(c) The Author(s) 2020. Open Access This article is licensed under a Creative Commons Attribution 4.0 International License, which permits use, sharing, adaptation, distribution and reproduction in any medium or format, as long as you give appropriate credit to the original author(s) and the source, provide a link to the Creative Commons licence, and indicate if changes were made. The images or other third party material in this article are included in the article's Creative Commons licence, unless indicated otherwise in a credit line to the material. If material is not included in the article's Creative Commons licence and your intended use is not permitted by statutory regulation or exceeds the permitted use, you will need to obtain permission directly from the copyright holder. To view a copy of this licence, visit http://creativecommons.org/licenses/by/4.0/. The Creative Commons Public Domain Dedication waiver (http://creativeco mmons.org/publicdomain/zero/1.0/) applies to the data made available in this article, unless otherwise stated in a credit line to the data. 
Trial registration The identifier of the Maternal and Newborn Health Registry at ClinicalTrials.gov is NCT01073475.Trial registration: The identifier of the Maternal and Newborn Health Registry at ClinicalTrials.gov is NCT01073475.

Keywords: Preterm, Low birth weight, Low and middle-income countries, Global network, Risk factors, India, Africa, Guatemala

\section{Background}

Addressing the global burden of preterm birth (before 37 weeks of pregnancy) is critical to reducing neonatal and childhood mortality and to achieving Sustainable Development Goal \#3-to ensure healthy lives and to promote well-being for all at all ages [1]. The World Health Organization (WHO) estimates that there are 15 million preterm births every year [2]. Gestational age is more predictive of risk of neonatal and childhood mortality than low birth weight (LBW-below $2500 \mathrm{~g}$ ), but prematurity is more difficult to ascertain accurately than birthweight. Ninety-seven percent of LBW babies are born in low and lower-middle income countries (LMIC) where estimates of gestational age are the most difficult to ascertain. Therefore, the WHO also estimates the number of babies born with LBW, currently 25 million babies annually [2]. Although prematurity is a major reason for a baby being born LBW, LBW is an imperfect surrogate for preterm birth. Term babies may also be LBW because they are growth restricted and small for gestational age (SGA) that weigh less than 10th percentile of weight for gestational age and sex, resulting in an estimated $67 \%$ overlap between preterm birth and LBW [3, 4]. Mechanisms and risk factors for preterm and for LBW babies may differ despite a substantial proportion of LBW being contributed by preterm births as LBW infants are also a result of intrauterine growth restriction [5]. LBW and/ or preterm birth are important causes of neonatal mortality. In 2015, there were an estimated 1 million deaths in children under age 5 years globally attributed to prematurity [6]. Infants who are SGA have an increased risk of neonatal mortality regardless of their association with preterm birth [7]. Thirty five percent of neonatal deaths were attributed to prematurity [8] and more than $80 \%$ of neonatal deaths were in LBW babies [9].

There have been calls for improved estimates of the burden of preterm birth and LBW, particularly in countries where the data are sparse, incomplete or not population-based [8]. There is limited information on maternal factors associated with these neonatal conditions and whether and how they may occur in rural settings in LMICs. More accurate data may enable government policies and programs to more effectively target interventions to reduce preterm birth and LBW. Neonatal mortality in LBW preterm babies is higher, with more severe lifelong consequences, than for LBW and preterm babies alone and therefore accurate estimates of and risk factors for the combination are needed to improve survival of these newborns [10].

The Eunice Kennedy Shriver National Institute of Child Health and Human Development's (NICHD's) Global Network (GN), is a multi-site research network representing partnerships of U.S. and international investigators at rural and semi-urban study sites in Guatemala, India (2 sites:Nagpur and Belgaum), Pakistan, Kenya, Zambia and the Democratic Republic of the Congo. The GN Maternal and Newborn Health Registry (MNHR) has been collecting data on a population-based sample of pregnant women and their babies starting in 2008 . The GN has consistently focused on improving the quality of its data [11], by focusing on obtaining accurate and standardized methods of assessing birth weight and gestational age data across all participating sites. Gestational age data has been improved over time by increased access to ultrasound dating, mostly from January 2014. Standardized training of sonographers has also been possible across the $\mathrm{GN}$ as ultrasounds were required for three GN studies [12-14] that drew their study participants from subjects participating in the MNHR. Here we describe and compare the rates of preterm births, LBW and a combination of preterm birth and LBW at the GN sites. We also explored and compared the maternal, delivery and infant characteristics as risk factors associated with preterm birth, LBW and both preterm birth and LBW for the GN sites.

\section{Methods}

\section{Study design, setting and participants}

This study is a secondary data analysis using the GN's population-based MNHR. The details of the MNHR have been published [15]. The MNHR started in 2008 and has registered approximately 70,000 pregnant women and their babies annually in rural and semi-urban communities in the countries listed above. Each site has included 6-24 distinct geographic locations (clusters). The registry continues to prospectively identify, consent, screen and enroll pregnant women in the study communities as early as possible in their pregnancy. The enrollment target in all participating communities (clusters) is at least 95\% of pregnant women. Pregnant women included in this analysis were screened, consented and enrolled in the MNHR between January 2014 and December 2018, 
since first trimester ultrasound for gestational age dating and quality assurance efforts to improve the accuracy of reporting of last menstrual period (LMP) were consistently adopted sites.

\section{Eligibility criteria}

Women were excluded from the analysis if they did not consent; were lost to follow-up prior to delivery; or if the information on gestational age at birth, vital status or birth weight was missing. Women who died prior to delivery, who had a miscarriage or medical termination of pregnancy, a multiple birth or a stillbirth were also excluded from analysis.

\section{Data collection process, co-variates and quality control}

Data on the enrolled women were collected by trained health workers at three time points: at enrolment (as early as possible in pregnancy: age, educational status, height [except in the Kenya site that did not collect maternal height until 2017], weight, maternal BMI collected on enrollment, parity, date of LMP, expected date of delivery, and hemoglobin levels [two sites that had data available for most of the study period]); at delivery (receipt of iron, vitamins or calcium and the tetanus toxoid immunization during this pregnancy; number of antenatal care (ANC)visits; antenatal ultrasound information; date of delivery; gender of the baby; birth weight; mode of delivery; maternal conditions such as obstructed labor, severe antepartum or postpartum hemorrhage, hypertensive disorders, and fetal malpresentation; neonatal status; and place of delivery); at 42 days postpartum (maternal mortality, neonatal survival, and hospitalizations of the mother or baby) [16-20].

Senior Foreign Investigators (on-site primary investigators) at all sites were trained centrally. They then trained their site's data collectors prior to collecting study data. Data sources included medical records as well as interviews with the participating women. Data collected on paper were entered into a database at a site-based data management center and transmitted to a central data coordinating center at Research Triangle Institute (RTI), Durham, NC, USA. RTI monitored the data with monthly reports of data quality (completeness and timeliness) and edit reports to identify out of range or inconsistent data that were then addressed by the site staff as well site visits.

\section{Outcomes}

The primary outcomes for the study were rates of preterm birth, rates of LBW and their combination. Preterm birth rate was defined as the number of neonates delivered before 37 completed weeks of gestation per 100 live births. Gestational age was estimated from the most reliable variable using the following hierarchy of reliability (1) ultrasound, (2) date of LMP, if menses are regular, (3) neonatal examination and (4) gestational age recorded at birth. The LMP was considered reliable if the LMP date given was consistent with other information about the pregnancy (i.e., plausible date), the pregnant woman states that she has a regular menstrual cycle, seems relatively sure of the date and was not using contraception. Ultrasound examinations were conducted either as a part of a GN study wherein standardized training was provided to sonologists or as a part of routine antenatal care. However, availability of ultrasound information any time during pregnancy with information on gestational age varied across sites. Additionally, babies with birthweight between the 99th percentile at 36 week (based on country-specific growth data: DRC $=3086$, Zam$\mathrm{bia}=3093$, Guatemala $=2959$, Belagavi, India $=2784$, Pakistan $=2849$, Nagpur $=2680, \quad$ Kenya $=3311$ ) and $5500 \mathrm{~g}$ were classified as term births $[21,22]$.

Low birth weight (LBW) rate was defined as the number of neonates with a birthweight less than 2,500 g per 100 live births. Birth weight was measured (not estimated) within 6 days of birth in more than $96.8 \%$ of neonates in the MNHR [15].

Preterm and LBW rate was defined as the number of neonates both preterm birth and LBW per 100 live births.

\section{Ethical clearance}

The Institutional Review Boards and Ethics Research Committees of all participating institutions approved the MNHR. Prior to initiation of the study, agreement to participate was obtained from the communities through sensitization meetings. Individual informed consent for study participation was required from each study participant. No monetary reimbursements were provided to study participants nor to the communities participating in the study. A Data Monitoring Committee appointed by NICHD oversaw and reviewed the study at annual meetings.

\section{Statistical analysis}

We computed summary statistics (e.g., $\mathrm{n}$ and proportions) overall and by GN site for rates of preterm birth, LBW and the combination of preterm and LBW, as well as maternal and neonatal characteristics. Generalized linear models (GLM) with generalized estimating equation (GEE) working correlation structure were used to evaluate the relationship of potential factors and preterm birth, LBW and the combination of preterm birth and LBW to develop point and interval estimates of relative risk associated with these factors. GEE were used to account for the correlation of outcomes within cluster to develop appropriate 
confidence intervals. The risk ratios for the factors associated with preterm birth, LBW, and their combination in the overall study population and by site are represented graphically and also described using multivariable regression analyses separately for preterm birth, LBW and their combination. All analyses were conducted in SAS 9.4 (RTI Inc., Durham, NC). A twosided $\mathrm{p}$-value $<0.05$ was considered to be statistically significant.

\section{Results}

From January 2014 to December 2018, a total of 303,883 women were screened. Among these, 272,192 (89.6\%) met the inclusion criteria of maternal survival through delivery and a pregnancy resulting in a singleton, live birth with gestational age and birth weight assessed.

These mother-baby pairs were analyzed for rates of preterm birth, LBW and the combination of both preterm birth and LBW (Fig. 1). For this population, gestational age was based on ultrasound for $18.5 \%$ of babies, LMP for $68.1 \%$, clinical exam for $1.6 \%$, as collected at delivery (usually by LMP) for $6.1 \%$, and weight for $5.7 \%$.

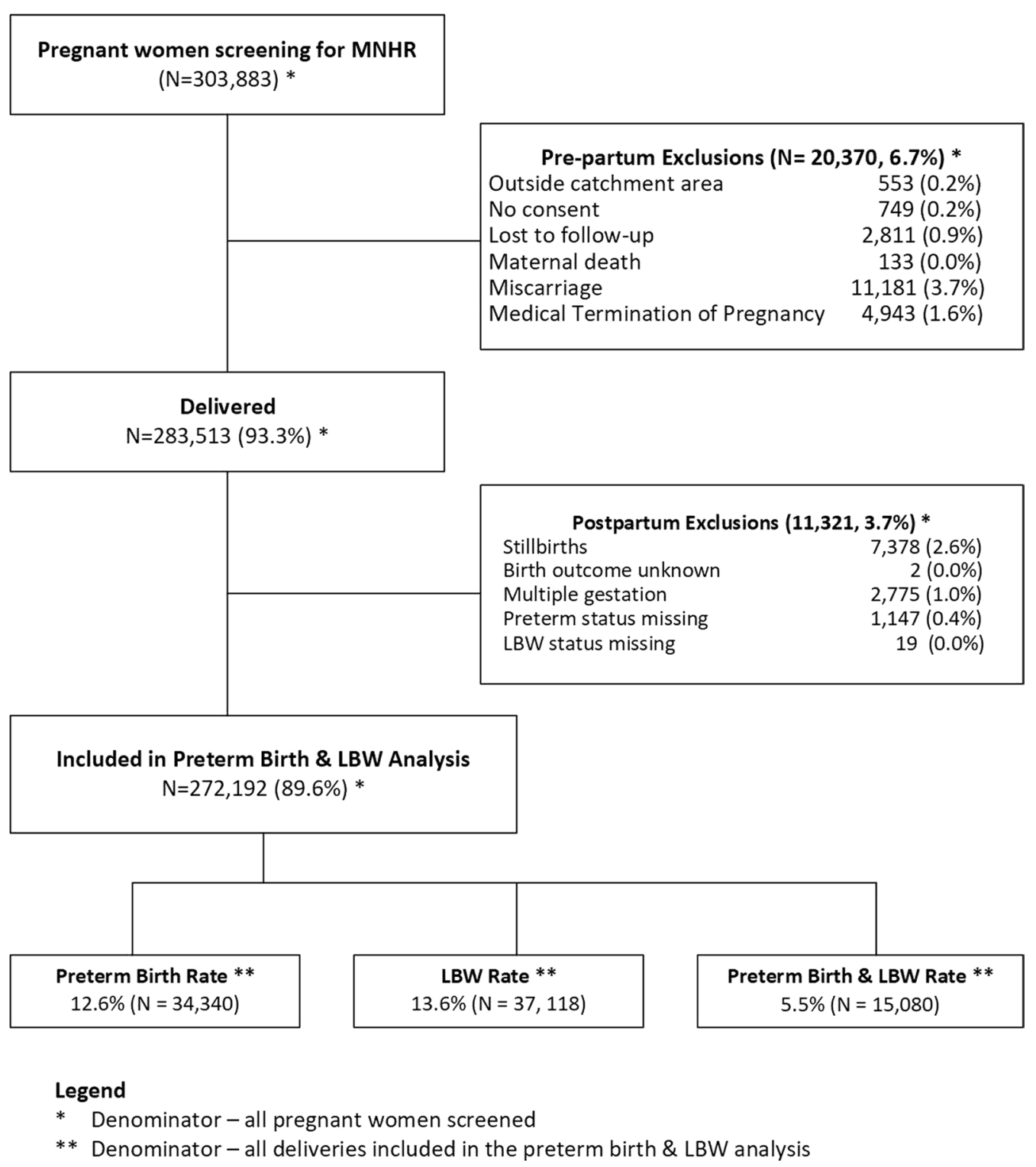

Fig. 1 Study flow diagram 


\section{Maternal, delivery and infant characteristics of the study population}

As shown in Table 1, more than $80 \%$ of the women were aged $20-35$ years across all GN sites, but $19-24 \%$ of the women in the Africa sites vs. $2-12 \%$ of the women in the Asian sites were less than age 20 years of age. Overall, almost $79 \%$ had completed at least primary and secondary education, but $82 \%$ of women in the Pakistani site and $38 \%$ of women in the DRC site had no formal education.
Overall, $31 \%$ of the women were nulliparous, ranging from $17 \%$ in the Pakistani site to $50 \%$ in the Nagpur site. During antenatal period, more than $94 \%$ of the women received at least any one of iron, vitamins or calcium in all sites, except in the Pakistani site where only $82 \%$ had received one or more of these supplements. A similar pattern was seen with administration of tetanus toxoid (76\% or more in all sites were immunized except in the Pakistan site, where the rate was 51\%).

Table 1 Maternal, delivery and infant characteristics by Global Network Site

\begin{tabular}{|c|c|c|c|c|c|c|c|c|}
\hline Characteristic & Overall, all sites & DRC & Zambia & Kenya & Guatemala & Belagavi, India & Nagpur, India & Pakistan \\
\hline Deliveries, N & 272,192 & 29,796 & 33,918 & 36,166 & 52,047 & 40,172 & 41,894 & 38,199 \\
\hline Maternal age & 272,094 & 29,767 & 33,906 & 36,110 & 52,047 & 40,172 & 41,894 & 38,198 \\
\hline$<20$ & $38,388(14.1)$ & $5744(19.3)$ & $194(24.2)$ & $8166(22.6)$ & $8915(17.1)$ & $4684(11.7)$ & $981(2.3)$ & $1704(4.5)$ \\
\hline $20-35$ & $219,304(80.6)$ & $21,493(72.2)$ & $22,992(67.8)$ & $26,402(73.1)$ & $37,865(72.8)$ & $35,360(88.0)$ & $40,701(97.2)$ & $34,491(90.3)$ \\
\hline$>35$ & $14,402(5.3)$ & $2530(8.5)$ & $2720(8.0)$ & $1,542(4.3)$ & $5267(10.1)$ & $128(0.3)$ & $212(0.5)$ & $2003(5.2)$ \\
\hline Maternal education & 272,095 & 29,795 & 33,910 & 36,119 & 52,047 & 40,170 & 41,858 & 38,196 \\
\hline No formal education & $58,512(21.5)$ & $11,278(37.9)$ & $2509(7.4)$ & $528(1.5)$ & $6428(12.4)$ & $5236(13.0)$ & $1296(3.1)$ & $31,237(81.8)$ \\
\hline Primary/secondary & $195,792(72.0)$ & $18,450(61.9)$ & $30,903(91.1)$ & $32,458(89.9)$ & $42,076(80.8)$ & $31,346(78.0)$ & $34,140(81.6)$ & 6419 (16.8) \\
\hline University+ & $17,791(6.5)$ & $67(0.2)$ & $498(1.5)$ & $3133(8.7)$ & $3543(6.8)$ & $3588(8.9)$ & $6422(15.3)$ & $540(1.4)$ \\
\hline Parity & 270,083 & 29,795 & 33,915 & 36,124 & 52,046 & 40,170 & 41,867 & 36,166 \\
\hline 0 & $84,753(31.4)$ & $5,598(18.8)$ & $10,454(30.8)$ & $11,737(32.5)$ & $15,479(29.7)$ & $14,585(36.3)$ & $20,804(49.7)$ & $6,096(16.9)$ \\
\hline $1-2$ & $113,835(42.1)$ & $9350(31.4)$ & $13,300(39.2)$ & $14,136(39.1)$ & $20,972(40.3)$ & $22,795(56.7)$ & $20,239(48.3)$ & $13,043(36.1)$ \\
\hline$>2$ & $71,495(26.5)$ & $14,847(49.8)$ & $10,161(30.0)$ & $10,251(28.4)$ & $15,595(30.0)$ & $2,790(6.9)$ & $824(2.0)$ & $17,027(47.1)$ \\
\hline $\begin{array}{l}\text { Antenatal iron/calcium/ } \\
\text { vitamins }\end{array}$ & 272,136 & 29,790 & 33,918 & 36,166 & 52,044 & 40,166 & 41,854 & 38,198 \\
\hline Received any & $260,290(95.6)$ & $28,087(94.3)$ & 33,847 (99.8) & $35,558(98.3)$ & $50,117(96.3)$ & $39,474(98.3)$ & $41,751(99.8)$ & $31,456(82.3)$ \\
\hline $\begin{array}{l}\text { Tetanus toxoid immuni- } \\
\text { zation received }\end{array}$ & 272,079 & 29,789 & 33,917 & 36,166 & 51,967 & 40,170 & 41,871 & 38,199 \\
\hline Yes & $230,906(84.9)$ & $26,108(87.6)$ & $30,911(91.1)$ & $32,884(90.9)$ & $39,514(76.0)$ & $40,117(99.9)$ & $41,791(99.8)$ & $19,581(51.3)$ \\
\hline At least one ANC visit & 272,155 & 29,796 & 33,918 & 36,164 & 52,036 & 40,171 & 41,872 & 38,198 \\
\hline Yes & $266,816(98.0)$ & $28,775(96.6)$ & $33,889(99.9)$ & $35,826(99.1)$ & $49,841(95.8)$ & $40,159(100.0)$ & $41,763(99.7)$ & $36,563(95.7)$ \\
\hline Number of ANC visits & 271,910 & 29,758 & 33,916 & 36,138 & 51,961 & 40,166 & 41,798 & 38,173 \\
\hline 0 & $5339(2.0)$ & $1021(3.4)$ & $29(0.1)$ & $338(0.9)$ & $2195(4.2)$ & $12(0.0)$ & $109(0.3)$ & $1635(4.3)$ \\
\hline $1-3$ & $102,119(37.6)$ & $14,790(49.7)$ & $17,978(53.0)$ & $15,044(41.6)$ & $16,968(32.7)$ & $10,642(26.5)$ & $5,415(13.0)$ & $21,282(55.8)$ \\
\hline $4+$ & $164,452(60.5)$ & $13,947(46.9)$ & $15,909(46.9)$ & $20,756(57.4)$ & $32,798(63.1)$ & $29,512(73.5)$ & $36,274(86.8)$ & $15,256(40.0)$ \\
\hline Obstructive labor & 272,180 & 29,796 & 33,918 & 36,166 & 52,045 & 40,171 & 41,885 & 38,199 \\
\hline Yes & $14,021(5.2)$ & $438(1.5)$ & $869(2.6)$ & $1148(3.2)$ & $2271(4.4)$ & $3433(8.5)$ & $468(8.3)$ & $2394(6.3)$ \\
\hline $\begin{array}{l}\text { Severe antepartum } \\
\text { hemorrhage }\end{array}$ & 272,179 & 29,796 & 33,917 & 36,166 & 52,043 & 40,171 & 41,887 & 38,199 \\
\hline Yes & $1361(0.5)$ & $60(0.2)$ & $162(0.5)$ & $202(0.6)$ & $124(0.2)$ & $179(0.4)$ & $71(0.2)$ & $563(1.5)$ \\
\hline $\begin{array}{l}\text { Severe postpartum } \\
\text { hemorrhage }\end{array}$ & 270,473 & 29,786 & 33,368 & 35,377 & 52,015 & 40,170 & 41,558 & 38,199 \\
\hline Yes & $3041(1.1)$ & $178(0.6)$ & $189(0.6)$ & $438(1.2)$ & $426(0.8)$ & $639(1.6)$ & $66(0.2)$ & $1105(2.9)$ \\
\hline Hypertensive disorders & 272,108 & 29,744 & 33,913 & 36,165 & 52,032 & 40,171 & 41,887 & 38,196 \\
\hline Yes & $5904(2.2)$ & $12(0.0)$ & $284(0.8)$ & $150(0.4)$ & $2069(4.0)$ & $1538(3.8)$ & $983(2.3)$ & $868(2.3)$ \\
\hline Fetal malpresentation & 272,154 & 29,774 & 33,917 & 36,163 & 52,044 & 40,171 & 41,886 & 38,199 \\
\hline Yes & $4564(1.7)$ & $108(0.4)$ & $196(0.6)$ & $260(0.7)$ & $1499(2.9)$ & $653(1.6)$ & $755(1.8)$ & $1093(2.9)$ \\
\hline Sex of the baby & 272,177 & 29,794 & 33,915 & 36,166 & 52,043 & 40,169 & 41,892 & 38,198 \\
\hline Female & $132,674(48.7)$ & 14,351 (48.2) & $16,794(49.5)$ & $18,026(49.8)$ & $25,428(48.9)$ & 19,391 (48.3) & $20,141(48.1)$ & $18,543(48.5)$ \\
\hline
\end{tabular}


Overall, $60 \%$ of the women had four or more antenatal care (ANC) visits, with the Pakistani site having only $40 \%$ of women who had at least four ANC visits. Maternal hypertensive disorders were reported to be more common in the Asian and Guatemalan sites and lower in the African sites.

Severe antepartum hemorrhage was less than $0.6 \%$ in all sites except the Pakistani site (1.5\%) and fetal malpresentation was $0.7 \%$ or less in the African sites, but between $1.6 \%$ and $2.9 \%$ in the Asian and Guatemalan sites.

\section{Rates of preterm birth, LBW and preterm birth and LBW}

Figure 2a shows the rates of preterm birth, LBW, the combination of preterm birth and LBW as well as term, normal birth weight live births. The overall rate of preterm birth across the GN sites was $12.6 \%$. As shown in Fig. 2a, among the Asian sites, preterm birth rates were

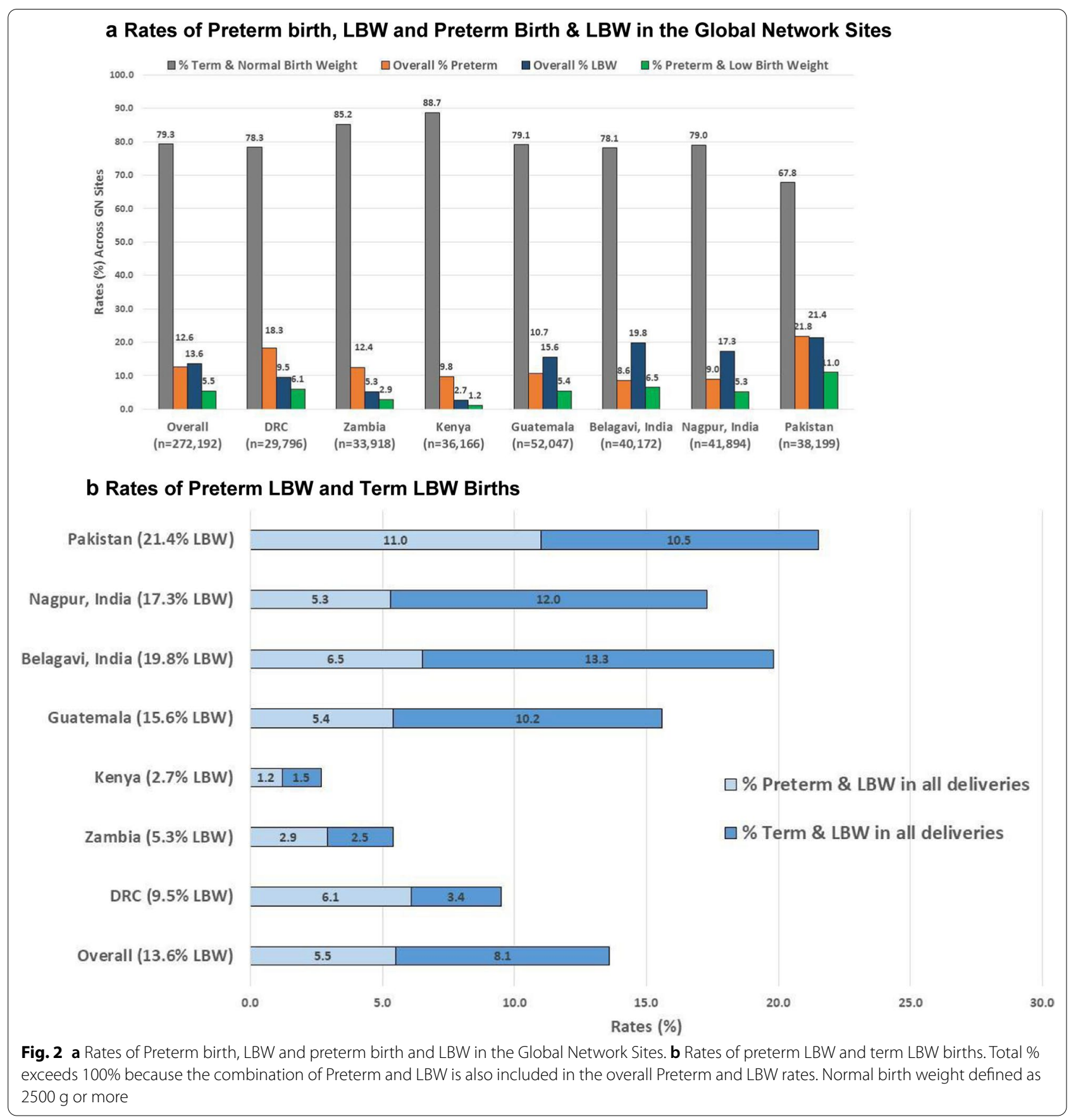


the highest in the Pakistani site (21.8\%) and lowest for the Belagavi site (8.6\%). Among the African sites, DRC had the highest preterm birth rate of $18.3 \%$. The overall LBW rate was $13.6 \%$, in the African sites ranging from 2.7\% (Kenyan site) to 9.5\% (DRC site), and in the Asian sites from 17.3\% (Nagpur site) to 21.4\% (Pakistani site). Figure $2 \mathrm{a}$ also shows the rates of babies with a combination of preterm birth and LBW at $5.5 \%$. Of note, the very low birth weight rate (those weighing $<1500 \mathrm{gm}$ ), was observed in $0.6 \%$ of the births overall, ranging from $0.2 \%$ in the Kenyan site to $1.1 \%$ in the Pakistani site.

Figure $2 \mathrm{~b}$ displays the variations across sites in the proportions of LBW babies who were preterm vs. term with the Indian sites and the Guatemalan site having higher percent of term LBW babies.

Risk factors associated with preterm birth, LBW and preterm birth and LBW Risk factors associated with preterm Birth

As shown in Fig. 3, factors associated with increased risk of preterm birth in most (at least 4 of the 7 sites) GN sites included younger maternal age $<20$ years, no formal education, no receipt of antenatal iron, calcium or vitamins, less than four ANC visits, severe antepartum hemorrhage, maternal hypertensive disorders, and fetal malpresentation. Of note, female gender and nulliparity was associated with preterm births at the African sites but not in the Asian sites or the Guatemalan site. Obstructed labor was associated with a decreased risk for preterm birth at most sites (see Table 2).

\section{Risk factors associated with LBW}

Figure 3 shows that the overall risk factors for LBW were similar to the risk factors for preterm birth. As shown in Table 3, the risk factors for LBW included maternal age $<20$ years, no formal education or only primary and secondary education, nulliparity, no receipt of iron, calcium or vitamins, less than four ANC visits, severe antepartum hemorrhage, maternal hypertensive disorders and fetal malpresentation. Female neonates were more likely to be LBW in all sites.

\section{Risk factors associated with both preterm birth and LBW}

Figure 3 shows that the risk factors for having both a LBW and preterm birth were similar to having either a preterm or LBW birth.

However, the effect size of the antenatal care, antepartum hemorrhage and hypertensive disorder risk factors were higher than for preterm birth or LBW alone (see Table 4).

\section{Risk factors available at select sites}

Maternal BMI was available in all sites except the Kenya site. $\mathrm{BMI}<18.5 \mathrm{~kg} / \mathrm{m}^{2}$ was a risk factor for preterm birth at all sites and LBW at nearly all sites. Maternal hemoglobin was consistently available over the study period in the two Indian sites. Mild anemia (hemoglobin 10.0-10.9 g/dL) was associated only with LBW in the Nagpur site and not associated with preterm at either of the sites. Moderate to severe anemia $(<10 \mathrm{~g} /$ $\mathrm{dL}$ ) was associated with preterm birth, LBW, and the combination of preterm birth and LBW when data from the two Indian sites were combined.

\section{Discussion}

The Global Network's population-based estimate of the preterm birth rate was $12.6 \%$ with the highest rates in the Pakistani and the DRC sites and the lowest rates $(<10 \%)$ in the Indian and Kenyan sites. LBW rates were $13.6 \%$ but showed a different pattern with the highest rates in the Asian and Guatemalan sites and the lowest rates in the African sites. The combination of preterm birth and LBW was highest in the Pakistani site (11\%) and lowest in the Kenyan site (1.2\%).

Our rural and semi-urban population rates for preterm birth are similar to country-wide estimates in previously reported studies [23-28]. However, our results are higher than recent global estimates for preterm birth in 2014 (10.6\% - uncertainty interval 9.0-12.0) [7]. Rates of preterm birth in the Pakistani and DRC sites were outliers among the GN sites and were associated with poor antenatal care indicators such as lack of receipt of antenatal iron, calcium and vitamins, lack of tetanus toxoid immunization and fewer than four antenatal visits [29-31]. The Asian sites had higher rates of LBW, likely because term and preterm birth weights are higher in the African sites and intrauterine growth retardation or SGA is more common in the Asian sites as observed in other studies [32-36].

Our estimates of LBW are slightly lower, but within range of recent global estimates for LBW in 2015 (14.6\%-uncertainty range $12.4-17.1 \%)$ [8]. To our knowledge, there are no prior global estimates of the combination of both preterm and LBW. Risk factors for having a preterm birth and LBW baby are similar to those for each condition alone, likely because of the overlap of these outcomes. They include poor ANC indicators such as less than four ANC visits, nulliparity and maternal age under age 20 [37], severe antepartum hemorrhage and hypertensive disorders. The similarity of risk factors for preterm birth, LBW and the combination of preterm birth and LBW in the GN sites suggest an important need to monitor those women with 


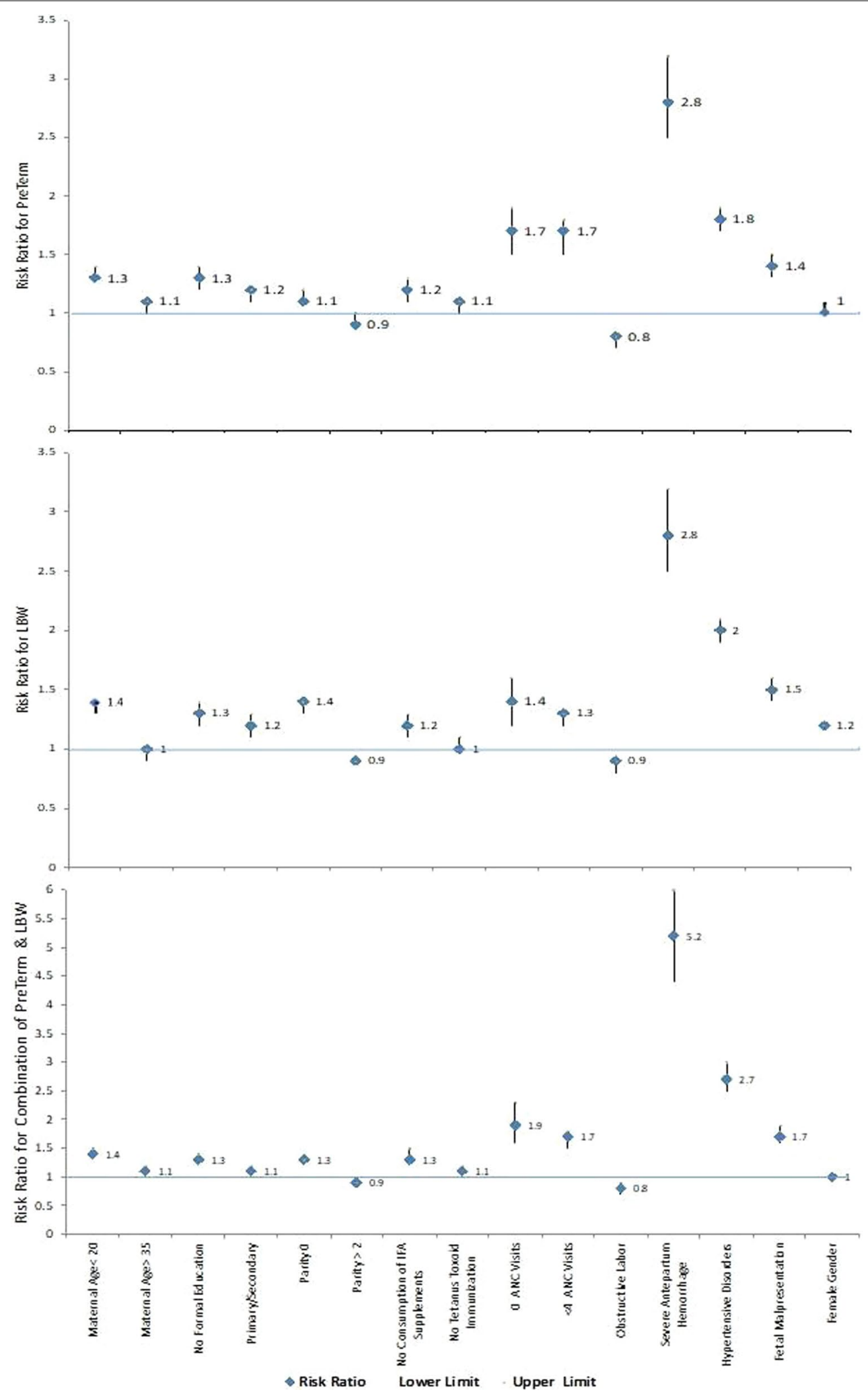

Fig. 3 Overall risk ratios for preterm birth, LBW and preterm birth and LBW 
Table 2 Maternal, delivery and infant characteristics as risk factors for preterm birth-overall and site-specific risk ratios with $95 \%$ confidence intervals and $p$ values

\begin{tabular}{|c|c|c|c|c|c|c|c|c|}
\hline \multirow[t]{2}{*}{ Characteristic } & \multicolumn{8}{|c|}{ Relative risk $(95 \% \mathrm{Cl}), \mathrm{p}$-value } \\
\hline & $\begin{array}{l}\text { Overall, all } \\
\text { sites }\end{array}$ & DRC & Zambia & Kenya & Guatemala & Belagavi & Nagpur & Pakistan \\
\hline $\begin{array}{l}\text { Maternal age } \\
(20-35)\end{array}$ & 1.0 & 1.0 & 1.0 & 1.0 & 1.0 & 1.0 & 1.0 & 1.0 \\
\hline$<20$ & $\begin{array}{l}1.31 \\
(1.26,1.37) \\
<.0001\end{array}$ & $\begin{array}{l}1.45(1.30 \\
1.63),<.0001\end{array}$ & $\begin{array}{l}1.36(1.28 \\
1.44),<.0001\end{array}$ & $\begin{array}{l}1.51(1.40 \\
1.62),<.0001\end{array}$ & $\begin{array}{l}1.30(1.22 \\
1.38),<.0001\end{array}$ & $\begin{array}{l}1.09(0.99 \\
1.20), 0.0880\end{array}$ & $\begin{array}{l}1.25(1.07 \\
1.47), 0.0061\end{array}$ & $\begin{array}{l}1.05(0.93,1.20) \\
0.4115\end{array}$ \\
\hline$>35$ & $\begin{array}{l}1.07 \\
(1.02,1.12) \\
0.0078\end{array}$ & $\begin{array}{l}1.08(1.00 \\
1.18), 0.0636\end{array}$ & $\begin{array}{l}1.13(1.02 \\
1.25), 0.0196\end{array}$ & $\begin{array}{l}1.05(0.93 \\
1.19), 0.3893\end{array}$ & $\begin{array}{l}1.13(1.02 \\
1.24), 0.0151\end{array}$ & $\begin{array}{l}2.22(1.56 \\
3.16),<.0001\end{array}$ & $\begin{array}{l}1.00(0.68 \\
1.49), 0.9847\end{array}$ & $\begin{array}{l}0.94(0.86,1.03) \\
0.1647\end{array}$ \\
\hline $\begin{array}{l}\text { Maternal } \\
\text { education } \\
\text { (University+) }\end{array}$ & 1.0 & 1.0 & 1.0 & 1.0 & 1.0 & 1.0 & 1.0 & 1.0 \\
\hline $\begin{array}{l}\text { No formal } \\
\text { education }\end{array}$ & $\begin{array}{l}1.32 \\
(1.23,1.41) \\
<.0001\end{array}$ & $\begin{array}{l}2.30(1.01 \\
5.25), 0.0474\end{array}$ & $\begin{array}{l}1.77(1.46 \\
2.14),<.0001\end{array}$ & $\begin{array}{l}1.48(1.04 \\
2.09), 0.0294\end{array}$ & $\begin{array}{l}1.18(0.97 \\
1.44), 0.0969\end{array}$ & $\begin{array}{l}1.29(1.11 \\
1.48), 0.0006\end{array}$ & $\begin{array}{l}1.50(1.27 \\
1.77),<.0001\end{array}$ & $\begin{array}{l}1.13(0.94,1.35) \\
0.1895\end{array}$ \\
\hline $\begin{array}{l}\text { Primary/sec- } \\
\text { ondary }\end{array}$ & $\begin{array}{l}1.17 \\
\quad(1.11,1.23) \\
<.0001\end{array}$ & $\begin{array}{l}2.20(0.94 \\
5.14), 0.0684\end{array}$ & $\begin{array}{l}1.57(1.26 \\
1.95),<.0001\end{array}$ & $\begin{array}{l}1.23(1.08 \\
1.40), 0.0013\end{array}$ & $\begin{array}{l}1.07(0.91 \\
1.25), 0.4209\end{array}$ & $\begin{array}{l}1.01(0.92 \\
1.12), 0.7693\end{array}$ & $\begin{array}{l}1.39(1.27 \\
1.52),<.0001\end{array}$ & $\begin{array}{l}1.01(0.86,1.18) \\
0.9492\end{array}$ \\
\hline Parity (1-2) & 1.0 & 1.0 & 1.0 & 1.0 & 1.0 & 1.0 & 1.0 & 1.0 \\
\hline 0 & $\begin{array}{l}1.12(1.07 \\
1.16),<.0001\end{array}$ & $\begin{array}{l}1.49(1.37 \\
1.62),<.0001\end{array}$ & $\begin{array}{l}1.13(1.05 \\
1.23), 0.0018\end{array}$ & $\begin{array}{l}1.39(1.25 \\
1.55),<.0001\end{array}$ & $\begin{array}{l}1.00(0.94 \\
1.06), 0.9133\end{array}$ & $\begin{array}{l}1.10(0.98 \\
1.24), 0.0944\end{array}$ & $\begin{array}{l}1.05(0.98 \\
1.12), 0.1429\end{array}$ & $\begin{array}{l}0.98(0.92,1.05) \\
0.5708\end{array}$ \\
\hline$>2$ & $\begin{array}{l}0.93(0.89 \\
0.97), 0.0002\end{array}$ & $\begin{array}{l}0.95(0.88 \\
1.02), 0.1329\end{array}$ & $\begin{array}{l}0.95(0.88 \\
1.03), 0.2046\end{array}$ & $\begin{array}{l}1.11(1.03 \\
1.19), 0.0045\end{array}$ & $\begin{array}{l}0.94(0.87 \\
1.02), 0.1227\end{array}$ & $\begin{array}{l}1.07(0.96 \\
1.19), 0.2446\end{array}$ & $\begin{array}{l}1.31(1.04 \\
1.65), 0.0243\end{array}$ & $\begin{array}{l}0.87(0.82,0.92) \\
\quad<.0001\end{array}$ \\
\hline $\begin{array}{c}\text { Consumption } \\
\text { of vitamins/ } \\
\text { calcium/iron }\end{array}$ & 1.0 & 1.0 & 1.0 & 1.0 & 1.0 & 1.0 & 1.0 & 1.0 \\
\hline $\begin{array}{l}\text { Not con- } \\
\text { sumed }\end{array}$ & $\begin{array}{l}1.18(1.11 \\
1.25),<.0001\end{array}$ & $\begin{array}{l}1.33(1.20 \\
1.47),<.0001\end{array}$ & $\begin{array}{l}1.24(0.59 \\
2.61), 0.5700\end{array}$ & $\begin{array}{l}1.46(1.07 \\
2.00), 0.0178\end{array}$ & $\begin{array}{l}1.10(0.98 \\
1.23), 0.1168\end{array}$ & $\begin{array}{l}1.78(1.53 \\
2.08),<.0001\end{array}$ & $\begin{array}{l}1.29(0.86 \\
1.93), 0.2139\end{array}$ & $\begin{array}{l}1.06(1.03,1.10), \\
0.0006\end{array}$ \\
\hline $\begin{array}{l}\text { Received teta- } \\
\text { nus toxoid } \\
\text { immunization }\end{array}$ & 1.0 & 1.0 & 1.0 & 1.0 & 1.0 & 1.0 & 1.0 & 1.0 \\
\hline $\begin{array}{l}\text { Did not } \\
\text { receive }\end{array}$ & $\begin{array}{l}1.08(1.02 \\
1.14), 0.0050\end{array}$ & $\begin{array}{l}1.15(0.99 \\
1.32), 0.0656\end{array}$ & $\begin{array}{l}0.90(0.75 \\
1.07), 0.2436\end{array}$ & $\begin{array}{l}1.10(0.96 \\
1.27), 0.1796\end{array}$ & $\begin{array}{l}0.96(0.88 \\
1.05), 0.3776\end{array}$ & $\begin{array}{l}0.89 \\
(0.30,2.64) \\
0.8286\end{array}$ & $\begin{array}{l}1.39 \\
(0.98,1.97) \\
0.0680\end{array}$ & $\begin{array}{l}1.12(1.07,1.18) \\
<.0001\end{array}$ \\
\hline $\begin{array}{l}\text { Number of ANC } \\
\text { visits }(4+)\end{array}$ & 1.0 & 1.0 & 1.0 & 1.0 & 1.0 & 1.0 & 1.0 & 1.0 \\
\hline 0 & $\begin{array}{l}1.66(1.46 \\
1.88),<.0001\end{array}$ & $\begin{array}{l}2.42(1.90 \\
3.07),<.0001\end{array}$ & $\begin{array}{l}3.97(1.61 \\
9.77), 0.0027\end{array}$ & $\begin{array}{l}3.28(2.58 \\
4.15),<.0001\end{array}$ & $\begin{array}{l}1.17(1.02 \\
1.34), 0.0217\end{array}$ & $\begin{array}{l}2.33(0.89 \\
6.14), 0.0856\end{array}$ & $\begin{array}{l}0.42(0.17 \\
1.03), 0.0590\end{array}$ & $\begin{array}{l}1.30(1.14,1.47) \\
<.0001\end{array}$ \\
\hline $1-3$ & $\begin{array}{l}1.65(1.54 \\
1.78),<.0001\end{array}$ & $\begin{array}{l}2.14(1.85 \\
2.47),<.0001\end{array}$ & $\begin{array}{l}2.48(2.05 \\
3.00),<.0001\end{array}$ & $\begin{array}{l}2.04(1.85 \\
2.24),<.0001\end{array}$ & $\begin{array}{l}1.52(1.43 \\
1.63),<.0001\end{array}$ & $\begin{array}{l}1.83(1.61 \\
2.08),<.0001\end{array}$ & $\begin{array}{l}1.30(1.08 \\
1.56), 0.0050\end{array}$ & $\begin{array}{l}1.16(1.11,1.21) \\
<.0001\end{array}$ \\
\hline $\begin{array}{l}\text { No obstructive } \\
\text { labor }\end{array}$ & 1.0 & 1.0 & 1.0 & 1.0 & 1.0 & 1.0 & 1.0 & 1.0 \\
\hline $\begin{array}{l}\text { Had obstruc- } \\
\text { tive labor }\end{array}$ & $\begin{array}{l}0.77(0.72, \\
0.82),<.0001\end{array}$ & $\begin{array}{l}0.88(0.77 \\
1.00), 0.0417\end{array}$ & $\begin{array}{l}0.97(0.77 \\
1.20), 0.7559\end{array}$ & $\begin{array}{l}0.82(0.68 \\
0.99), 0.0405\end{array}$ & $\begin{array}{l}0.67(0.53 \\
0.83), 0.0004\end{array}$ & $\begin{array}{l}0.80(0.65 \\
0.97), 0.0255\end{array}$ & $\begin{array}{l}0.70(0.60 \\
0.81),<.0001\end{array}$ & $\begin{array}{l}0.75(0.68 \\
0.83),<.0001\end{array}$ \\
\hline $\begin{array}{l}\text { No severe } \\
\text { antepartum } \\
\text { hemorrhage }\end{array}$ & 1.0 & 1.0 & 1.0 & 1.0 & 1.0 & 1.0 & 1.0 & 1.0 \\
\hline $\begin{array}{l}\text { Had severe } \\
\text { antepartum } \\
\text { hemor- } \\
\text { rhage }\end{array}$ & $\begin{array}{l}2.81(2.49 \\
3.18),<.0001\end{array}$ & $\begin{array}{l}2.54(1.94 \\
3.32),<.0001\end{array}$ & $\begin{array}{l}2.89(1.99 \\
4.21),<.0001\end{array}$ & $\begin{array}{l}1.97(1.50 \\
2.57),<.0001\end{array}$ & $\begin{array}{l}4.66(3.80 \\
5.72),<.0001\end{array}$ & $\begin{array}{l}5.63(4.80 \\
6.60),<.0001\end{array}$ & $\begin{array}{l}5.19(4.17 \\
6.45),<.0001\end{array}$ & $\begin{array}{l}1.92(1.76,2.09) \\
<.0001\end{array}$ \\
\hline $\begin{array}{l}\text { No severe } \\
\text { postpartum } \\
\text { hemorrhage }\end{array}$ & 1.0 & 1.0 & 1.0 & 1.0 & 1.0 & 1.0 & 1.0 & 1.0 \\
\hline
\end{tabular}


Table 2 (continued)

\begin{tabular}{|c|c|c|c|c|c|c|c|c|}
\hline \multirow[t]{2}{*}{ Characteristic } & \multicolumn{8}{|c|}{ Relative risk $(95 \% \mathrm{Cl}), \mathrm{p}$-value } \\
\hline & $\begin{array}{l}\text { Overall, all } \\
\text { sites }\end{array}$ & DRC & Zambia & Kenya & Guatemala & Belagavi & Nagpur & Pakistan \\
\hline $\begin{array}{l}\text { Had severe } \\
\text { postpartum } \\
\text { hemor- } \\
\text { rhage }\end{array}$ & $\begin{array}{l}0.93(0.84 \\
\quad 1.02), 0.1369\end{array}$ & $\begin{array}{l}0.91(0.65 \\
1.27), 0.5680\end{array}$ & $\begin{array}{l}1.01(0.69 \\
1.47), 0.9742\end{array}$ & $\begin{array}{l}1.11(0.93 \\
1.34), 0.2493\end{array}$ & $\begin{array}{l}1.24(0.93 \\
1.67), 0.1460\end{array}$ & $\begin{array}{l}0.96(0.78 \\
\quad 1.18), 0.6729\end{array}$ & $\begin{array}{l}1.52(0.83 \\
2.77), 0.1721\end{array}$ & $\begin{array}{l}0.81(0.74,0.89) \\
\quad<.0001\end{array}$ \\
\hline $\begin{array}{l}\text { No hyperten- } \\
\text { sive disorders }\end{array}$ & 1.0 & 1.0 & 1.0 & 1.0 & 1.0 & 1.0 & 1.0 & 1.0 \\
\hline $\begin{array}{l}\text { Had hyper- } \\
\text { tensive } \\
\text { disorders }\end{array}$ & $\begin{array}{l}1.81(1.68 \\
1.95),<.0001\end{array}$ & $\begin{array}{l}2.12(1.43 \\
\quad 3.15), 0.0002\end{array}$ & $\begin{array}{l}1.79(1.18 \\
2.72), 0.0062\end{array}$ & $\begin{array}{l}1.95(1.32 \\
2.87), 0.0008\end{array}$ & $\begin{array}{l}1.95(1.76 \\
2.17),<.0001\end{array}$ & $\begin{array}{l}2.52 \\
\quad(2.30,2.77) \\
<.0001\end{array}$ & $\begin{array}{l}2.30 \\
\quad(2.05,2.57) \\
<.0001\end{array}$ & $\begin{array}{l}1.19(1.05,1.35) \\
0.0075\end{array}$ \\
\hline $\begin{array}{l}\text { No fetal mal- } \\
\text { presentation }\end{array}$ & 1.0 & 1.0 & 1.0 & 1.0 & 1.0 & 1.0 & 1.0 & 1.0 \\
\hline $\begin{array}{l}\text { Had fetal } \\
\text { malpresen- } \\
\text { tation }\end{array}$ & $\begin{array}{l}1.35(1.26 \\
1.45),<.0001\end{array}$ & $\begin{array}{l}1.31(0.81 \\
2.09), 0.2679\end{array}$ & $\begin{array}{l}1.53(1.20 \\
1.97), 0.0007\end{array}$ & $\begin{array}{l}1.11(0.81 \\
\quad 1.53), 0.5165\end{array}$ & $\begin{array}{l}1.44(1.28 \\
1.62),<.0001\end{array}$ & $\begin{array}{l}1.65 \\
(1.26,2.15) \\
0.0002\end{array}$ & $\begin{array}{l}0.99 \\
(0.81,1.22), \\
0.9594\end{array}$ & $\begin{array}{l}1.34(1.20,1.50) \\
<.0001\end{array}$ \\
\hline $\begin{array}{l}\mathrm{BMI}, \mathrm{kg} / \mathrm{m}^{2} \\
\quad(18.5-24.9)\end{array}$ & 1.0 & 1.0 & 1.0 & & 1.0 & 1.0 & 1.0 & 1.0 \\
\hline$<18.5$ & $\begin{array}{l}1.18(1.15 \\
1.22),<.0001\end{array}$ & $\begin{array}{l}1.20(1.12 \\
1.28),<.0001\end{array}$ & $\begin{array}{l}1.19(1.03 \\
1.39), 0.0213\end{array}$ & $\square$ & $\begin{array}{l}1.22(0.98 \\
1.53), 0.0779\end{array}$ & $\begin{array}{l}1.26(1.16 \\
1.37),<.0001\end{array}$ & $\begin{array}{l}1.18(1.10 \\
1.26),<.0001\end{array}$ & $\begin{array}{l}1.18(1.11,1.25) \\
<.0001\end{array}$ \\
\hline$\geq 25.0$ & $\begin{array}{l}0.80(0.77 \\
0.83),<.0001\end{array}$ & $\begin{array}{l}0.73(0.63 \\
0.84),<.0001\end{array}$ & $\begin{array}{l}0.79(0.73 \\
0.85),<.0001\end{array}$ & $\square$ & $\begin{array}{l}0.78(0.73 \\
0.83),<.0001\end{array}$ & $\begin{array}{l}1.14(1.00 \\
1.29), 0.0529\end{array}$ & $\begin{array}{l}0.82(0.68 \\
0.98), 0.0336\end{array}$ & $\begin{array}{l}0.78(0.72,0.85) \\
\quad<.0001\end{array}$ \\
\hline $\begin{array}{l}\text { Hemoglobin } \\
\qquad \geq 11 \mathrm{~g} / \mathrm{dL})\end{array}$ & 1.0 & & & & & 1.0 & 1.0 & \\
\hline $\begin{array}{l}10.0-10.9 \mathrm{~g} / \\
\mathrm{dL} \text { (mild) }\end{array}$ & $\begin{array}{l}0.97(0.90 \\
1.04), 0.3626\end{array}$ & I & $\underline{\underline{E}}$ & $\underline{1}$ & 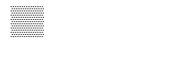 & $\begin{array}{l}0.92(0.82 \\
\quad 1.02), 0.1119\end{array}$ & $\begin{array}{l}1.04(0.97 \\
\quad 1.12), 0.2950\end{array}$ & I \\
\hline $\begin{array}{l}<10.0 \mathrm{~g} / \mathrm{dL} \\
\text { (moderate/ } \\
\text { severe) }\end{array}$ & $\begin{array}{l}1.10(1.04 \\
1.17), 0.0013\end{array}$ & 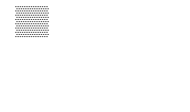 & $\underline{\underline{E}}$ & $\underline{\underline{\underline{E}}}$ & $\underline{E}$ & $\begin{array}{l}1.04(0.97 \\
1.12), 0.3015\end{array}$ & $\begin{array}{l}1.20(1.10 \\
1.30),<.0001\end{array}$ & $\underline{1}$ \\
\hline $\begin{array}{l}\text { Sex of the baby } \\
\text { (male) }\end{array}$ & 1.0 & 1.0 & 1.0 & 1.0 & 1.0 & 1.0 & 1.0 & 1.0 \\
\hline Female & $\begin{array}{l}1.03(1.01 \\
1.06), 0.0055\end{array}$ & $\begin{array}{l}1.14(1.08 \\
1.20),<.0001\end{array}$ & $\begin{array}{l}1.16(1.11 \\
1.21),<.0001\end{array}$ & $\begin{array}{l}1.10(1.05 \\
1.15),<.0001\end{array}$ & $\begin{array}{l}0.94(0.92 \\
0.97),<.0001\end{array}$ & $\begin{array}{l}0.87(0.82 \\
0.92),<.0001\end{array}$ & $\begin{array}{l}1.00(0.95 \\
1.06), 0.9464\end{array}$ & $\begin{array}{l}1.03(1.00,1.07) \\
0.0812\end{array}$ \\
\hline
\end{tabular}

-BMI not calculated for Kenya because maternal height was not recorded before 2017

\section{-maternal hemoglobin not consistently collected at all GN sites except Belagavi, India and Nagpur, India}

Generalized linear models were used to evaluate the relationship of potential factors and prematurity and to develop point and interval estimates of relative risk associated with these factors. Generalized estimating equations were used to account for the correlation of outcomes within cluster to develop appropriate confidence intervals. The reference group is indicated by 1.0 in the Risk Ratio column

these risk factors as it may help to improve their pregnancy outcomes.

Risk factors for prematurity, LBW and their combination varied by GN site. Therefore, the antenatal factors that are associated with these neonatal conditions may be monitored according to their region. The African sites had higher rates of preterm birth in the nulliparous women, whereas parity was not associated with preterm birth in the other GN sites. This was perhaps due to the higher proportion of women in Africa being $<20$ years of age and likely to have their first pregnancy at younger ages [31,37]. The other factor that was associated with increased risk for preterm birth in all sites was antepartum hemorrhage [38, 39]. The rates of preterm births were higher in the African sites. Whereas the rates of LBW were much higher in the non-African sites and so were the reported rates of hypertensive disorders. Hypertensive disorders are associated with SGA [40]. Another possible reason for higher rates of LBW in Asian sites could be higher rates of $\mathrm{BMI}<18.5 \mathrm{~kg} / \mathrm{m}^{2}$ and its association with LBW [41]. Moderate/severe anemia recorded anytime during pregnancy (data evaluated only for the Indian sites where enrollment in the study tended to be earlier in pregnancy than in other sites), either due to iron deficiency or other causes, increased the risk of both preterm birth and LBW. Anemia any time and especially during the rapid fetal growth during the third trimester is reported as an important factor in determining birth weight [18-20]. 
Table 3 Maternal, delivery and infant characteristics as risk factors for low birth weight-overall and site specific risk ratios with $95 \%$ confidence intervals and $p$ values

\begin{tabular}{|c|c|c|c|c|c|c|c|c|}
\hline \multirow[t]{2}{*}{ Characteristic } & \multicolumn{8}{|c|}{ Relative risk ( $95 \% \mathrm{Cl})$, p-value } \\
\hline & $\begin{array}{l}\text { Overall, all } \\
\text { sites }\end{array}$ & DRC & Zambia & Kenya & Guatemala & Belagavi & Nagpur & Pakistan \\
\hline $\begin{array}{l}\text { Maternal age } \\
(20-35)\end{array}$ & 1.0 & 1.0 & 1.0 & 1.0 & 1.0 & 1.0 & 1.0 & 1.0 \\
\hline$<20$ & $\begin{array}{l}1.35(1.30 \\
1.40),<.0001\end{array}$ & $\begin{array}{l}1.84(1.60 \\
2.10),<.0001\end{array}$ & $\begin{array}{l}1.67(1.49 \\
1.88),<.0001\end{array}$ & $\begin{array}{l}2.31(2.10 \\
2.55),<.0001\end{array}$ & $\begin{array}{l}1.23(1.17 \\
1.28),<.0001\end{array}$ & $\begin{array}{l}1.33(1.27 \\
1.39)_{,}<.0001\end{array}$ & $\begin{array}{l}1.23(1.11 \\
1.36),<.0001\end{array}$ & $\begin{array}{l}1.40(1.27,1.54) \\
<.0001\end{array}$ \\
\hline$>35$ & $\begin{array}{l}1.00(0.95 \\
1.05), 0.8649\end{array}$ & $\begin{array}{l}1.24(1.04 \\
1.49), 0.0177\end{array}$ & $\begin{array}{l}0.98(0.80 \\
1.21), 0.8748\end{array}$ & $\begin{array}{l}0.71(0.49 \\
\quad 1.02), 0.0655\end{array}$ & $\begin{array}{l}1.01(0.95 \\
1.07), 0.7819\end{array}$ & $\begin{array}{l}1.53(1.22 \\
1.91), 0.0002\end{array}$ & $\begin{array}{l}1.35(1.01 \\
1.79), 0.0392\end{array}$ & $\begin{array}{l}0.82(0.73,0.91) \\
0.0002\end{array}$ \\
\hline $\begin{array}{l}\text { Maternal } \\
\text { education } \\
\text { (University } \\
+ \text { ) }\end{array}$ & 1.0 & 1.0 & 1.0 & 1.0 & 1.0 & 1.0 & 1.0 & 1.0 \\
\hline $\begin{array}{l}\text { No formal } \\
\text { education }\end{array}$ & $\begin{array}{l}1.31(1.23 \\
1.38),<.0001\end{array}$ & $\begin{array}{c}4.56(1.56 \\
13.33) \\
0.0056\end{array}$ & $\begin{array}{l}0.76(0.60 \\
0.95), 0.0158\end{array}$ & $\begin{array}{l}1.21(0.78 \\
1.86), 0.3961\end{array}$ & $\begin{array}{l}1.16(1.08 \\
1.25),<.0001\end{array}$ & $\begin{array}{l}1.39(1.24 \\
1.55),<.0001\end{array}$ & $\begin{array}{l}1.11(0.95 \\
\quad 1.30), 0.1952\end{array}$ & $\begin{array}{l}1.31(1.12,1.53) \\
0.0009\end{array}$ \\
\hline $\begin{array}{l}\text { Primary/sec- } \\
\text { ondary }\end{array}$ & $\begin{array}{l}1.21(1.15 \\
1.27),<.0001\end{array}$ & $\begin{array}{c}4.38(1.49 \\
12.83) \\
0.0072\end{array}$ & $\begin{array}{l}0.88(0.76 \\
1.02), 0.0896\end{array}$ & $\begin{array}{l}0.91(0.74 \\
\quad 1.13), 0.4152\end{array}$ & $\begin{array}{l}1.16(1.08 \\
1.24)_{1}<.0001\end{array}$ & $\begin{array}{l}1.21(1.10 \\
1.33),<.0001\end{array}$ & $\begin{array}{l}1.26(1.16 \\
1.36),<.0001\end{array}$ & $\begin{array}{l}1.11(0.90,1.36) \\
0.3342\end{array}$ \\
\hline Parity (1-2) & 1.0 & 1.0 & 1.0 & 1.0 & 1.0 & 1.0 & 1.0 & 1.0 \\
\hline 0 & $\begin{array}{l}1.38(1.34,1.43) \\
<.0001\end{array}$ & $\begin{array}{l}1.86(1.69,2.05) \\
<.0001\end{array}$ & $\begin{array}{l}1.57(1.42,1.74) \\
<.0001\end{array}$ & $\begin{array}{l}2.23(1.93,2.59) \\
\quad<.0001\end{array}$ & $\begin{array}{l}1.26 \\
(1.20,1.32) \\
<.0001\end{array}$ & $\begin{array}{l}1.41(1.34 \\
1.50),<.0001\end{array}$ & $\begin{array}{l}1.38(1.32 \\
1.45),<.0001\end{array}$ & $\begin{array}{l}1.23(1.16,1.31) \\
<.0001\end{array}$ \\
\hline$>2$ & $\begin{array}{l}0.90(0.87 \\
0.93),<.0001\end{array}$ & $\begin{array}{l}0.86(0.79 \\
0.94), 0.0007\end{array}$ & $\begin{array}{l}0.90(0.83 \\
0.99), 0.0264\end{array}$ & $\begin{array}{l}0.78(0.67 \\
0.91), 0.0015\end{array}$ & $\begin{array}{l}0.93(0.87 \\
0.99), 0.0148\end{array}$ & $\begin{array}{l}0.91(0.85 \\
0.98), 0.0114\end{array}$ & $\begin{array}{l}1.01(0.86 \\
1.19), 0.8745\end{array}$ & $\begin{array}{l}0.85(0.80,0.89) \\
<.0001\end{array}$ \\
\hline $\begin{array}{l}\text { Consumption } \\
\text { of vitamins/ } \\
\text { calcium/iron }\end{array}$ & 1.0 & 1.0 & 1.0 & 1.0 & 1.0 & 1.0 & 1.0 & 1.0 \\
\hline $\begin{array}{l}\text { Not con- } \\
\text { sumed }\end{array}$ & $\begin{array}{l}1.18(1.10 \\
1.27),<.0001\end{array}$ & $\begin{array}{l}1.35(1.11 \\
\quad 1.64), 0.0030\end{array}$ & $\begin{array}{l}2.20(0.99 \\
4.89), 0.0521\end{array}$ & $\begin{array}{l}1.71(1.14 \\
2.58), 0.0100\end{array}$ & $\begin{array}{l}1.16(0.98 \\
1.36), 0.0779\end{array}$ & $\begin{array}{l}1.47(1.34 \\
1.62),<.0001\end{array}$ & $\begin{array}{l}0.81(0.60 \\
\quad 1.10), 0.1811\end{array}$ & $\begin{array}{l}1.10(1.03,1.17), \\
0.0027\end{array}$ \\
\hline $\begin{array}{l}\text { Received teta- } \\
\text { nus toxoid } \\
\text { immuniza- } \\
\text { tion }\end{array}$ & 1.0 & 1.0 & 1.0 & 1.0 & 1.0 & 1.0 & 1.0 & 1.0 \\
\hline $\begin{array}{l}\text { Did not } \\
\text { receive }\end{array}$ & $\begin{array}{l}1.03(0.97 \\
1.09), 0.3134\end{array}$ & $\begin{array}{l}1.15(0.90 \\
1.46), 0.2625\end{array}$ & $\begin{array}{l}0.66(0.48 \\
0.91), 0.0122\end{array}$ & $\begin{array}{l}0.73(0.52 \\
1.03), 0.0706\end{array}$ & $\begin{array}{l}0.93(0.87 \\
0.98), 0.0146\end{array}$ & $\begin{array}{l}0.85(0.53 \\
1.36), 0.5044\end{array}$ & $\begin{array}{l}0.89(0.61 \\
1.31), 0.5602\end{array}$ & $\begin{array}{l}1.14(1.07,1.21) \\
<.0001\end{array}$ \\
\hline $\begin{array}{l}\text { Number of } \\
\text { ANC visits } \\
(4+)\end{array}$ & 1.0 & 1.0 & 1.0 & 1.0 & 1.0 & 1.0 & 1.0 & 1.0 \\
\hline 0 & $\begin{array}{l}1.36(1.20 \\
1.55),<.0001\end{array}$ & $\begin{array}{l}2.48(1.83 \\
3.35),<.0001\end{array}$ & $\begin{array}{c}6.45(3.12 \\
13.33) \\
<.0001\end{array}$ & $\begin{array}{l}2.90(2.00 \\
4.20),<.0001\end{array}$ & $\begin{array}{l}1.20(0.96 \\
1.50), 0.1003\end{array}$ & $\begin{array}{l}1.26(0.53 \\
2.98), 0.5976\end{array}$ & $\begin{array}{l}0.65(0.44 \\
0.95), 0.0277\end{array}$ & $\begin{array}{l}1.25(1.09,1.44) \\
0.0015\end{array}$ \\
\hline $1-3$ & $\begin{array}{l}1.27(1.22 \\
1.31),<.0001\end{array}$ & $\begin{array}{l}1.88(1.58 \\
2.25),<.0001\end{array}$ & $\begin{array}{l}1.70(1.39 \\
2.07),<.0001\end{array}$ & $\begin{array}{l}1.48(1.28 \\
1.70),<.0001\end{array}$ & $\begin{array}{l}1.23(1.18 \\
1.28),<.0001\end{array}$ & $\begin{array}{l}1.33(1.26 \\
1.41),<.0001\end{array}$ & $\begin{array}{l}1.08(1.00 \\
1.16), 0.0399\end{array}$ & $\begin{array}{l}1.15(1.08,1.22) \\
<.0001\end{array}$ \\
\hline $\begin{array}{l}\text { No obstructive } \\
\text { labor }\end{array}$ & 1.0 & 1.0 & 1.0 & 1.0 & 1.0 & 1.0 & 1.0 & 1.0 \\
\hline $\begin{array}{l}\text { Had obstruc- } \\
\text { tive labor }\end{array}$ & $\begin{array}{l}0.85(0.80 \\
0.92),<.0001\end{array}$ & $\begin{array}{l}1.30(1.05 \\
1.60), 0.0151\end{array}$ & $\begin{array}{l}1.24(0.85 \\
1.81), 0.2691\end{array}$ & $\begin{array}{l}1.21(0.85 \\
1.72), 0.2813\end{array}$ & $\begin{array}{l}0.71(0.60 \\
0.84),<.0001\end{array}$ & $\begin{array}{l}0.90(0.79 \\
\quad 1.02), 0.1106\end{array}$ & $\begin{array}{l}0.82(0.74 \\
0.91), 0.0002\end{array}$ & $\begin{array}{l}0.88(0.80,0.96) \\
0.0042\end{array}$ \\
\hline $\begin{array}{l}\text { No severe } \\
\text { antepartum } \\
\text { hemorrhage }\end{array}$ & 1.0 & 1.0 & 1.0 & 1.0 & 1.0 & 1.0 & 1.0 & 1.0 \\
\hline $\begin{array}{l}\text { Had severe } \\
\text { antepar- } \\
\text { tum hem- } \\
\text { orrhage }\end{array}$ & $\begin{array}{l}2.82(2.53 \\
3.15),<.0001\end{array}$ & $\begin{array}{l}4.89(3.63 \\
6.59)_{,}<.0001\end{array}$ & $\begin{array}{l}6.56(5.09 \\
8.45),<.0001\end{array}$ & $\begin{array}{l}5.70(3.93 \\
8.27),<.0001\end{array}$ & $\begin{array}{l}3.63(3.18 \\
4.14)_{1}<.0001\end{array}$ & $\begin{array}{l}3.22 \\
\quad(2.74,3.80) \\
\quad<.0001\end{array}$ & $\begin{array}{l}3.05(2.43 \\
3.81),<.0001\end{array}$ & $\begin{array}{l}1.89(1.73,2.07) \\
<.0001\end{array}$ \\
\hline $\begin{array}{l}\text { No severe } \\
\text { postpartum } \\
\text { hemorrhage }\end{array}$ & 1.0 & 1.0 & 1.0 & 1.0 & 1.0 & 1.0 & 1.0 & 1.0 \\
\hline
\end{tabular}


Table 3 (continued)

\begin{tabular}{|c|c|c|c|c|c|c|c|c|}
\hline \multirow[t]{2}{*}{ Characteristic } & \multicolumn{8}{|c|}{ Relative risk ( $95 \% \mathrm{Cl})$, p-value } \\
\hline & $\begin{array}{l}\text { Overall, all } \\
\text { sites }\end{array}$ & DRC & Zambia & Kenya & Guatemala & Belagavi & Nagpur & Pakistan \\
\hline $\begin{array}{l}\text { Had severe } \\
\text { postpar- } \\
\text { tum hem- } \\
\text { orrhage }\end{array}$ & $\begin{array}{l}1.02(0.93 \\
1.12), 0.6406\end{array}$ & $\begin{array}{l}1.10(0.79 \\
\quad 1.53), 0.5741\end{array}$ & $\begin{array}{l}1.36(0.94 \\
1.97), 0.1036\end{array}$ & $\begin{array}{l}2.32(1.36 \\
3.97), 0.0021\end{array}$ & $\begin{array}{l}1.15(0.95 \\
1.38), 0.1438\end{array}$ & $\begin{array}{l}0.89(0.79 \\
\quad 1.01), 0.0805\end{array}$ & $\begin{array}{l}1.06(0.70 \\
1.60), 0.7964\end{array}$ & $\begin{array}{l}0.96(0.86,1.07) \\
0.4937\end{array}$ \\
\hline $\begin{array}{l}\text { No hyper- } \\
\text { tensive } \\
\text { disorders }\end{array}$ & 1.0 & 1.0 & 1.0 & 1.0 & 1.0 & 1.0 & 1.0 & 1.0 \\
\hline $\begin{array}{l}\text { Had hyper- } \\
\text { tensive } \\
\text { disorders }\end{array}$ & $\begin{array}{l}2.01(1.88 \\
2.15),<.0001\end{array}$ & $\begin{array}{l}1.72(0.87 \\
3.40), 0.1185\end{array}$ & $\begin{array}{l}3.52(2.57 \\
4.82),<.0001\end{array}$ & $\begin{array}{c}6.35(3.84 \\
10.50) \\
<.0001\end{array}$ & $\begin{array}{l}1.99(1.83 \\
2.16)_{1}<.0001\end{array}$ & $\begin{array}{l}1.98(1.86 \\
2.11),<.0001\end{array}$ & $\begin{array}{l}1.93(1.73 \\
2.14),<.0001\end{array}$ & $\begin{array}{l}1.31(1.16,1.47) \\
<.0001\end{array}$ \\
\hline $\begin{array}{l}\text { No fetal mal- } \\
\text { presentation }\end{array}$ & 1.0 & 1.0 & 1.0 & 1.0 & 1.0 & 1.0 & 1.0 & 1.0 \\
\hline $\begin{array}{l}\text { Had fetal } \\
\text { malpresen- } \\
\text { tation }\end{array}$ & $\begin{array}{l}1.45(1.35 \\
1.56),<.0001\end{array}$ & $\begin{array}{l}2.43(1.44 \\
\quad 4.08), 0.0008\end{array}$ & $\begin{array}{l}2.25(1.49 \\
3.39), 0.0001\end{array}$ & $\begin{array}{l}2.13(1.02 \\
\quad 4.44), 0.0432\end{array}$ & $\begin{array}{l}1.40(1.25 \\
1.56),<.0001\end{array}$ & $\begin{array}{l}1.38(1.16 \\
1.63), 0.0002\end{array}$ & $\begin{array}{l}1.28(1.09 \\
1.49), 0.0022\end{array}$ & $\begin{array}{l}1.41(1.28,1.56) \\
<.0001\end{array}$ \\
\hline $\begin{array}{l}\mathrm{BMI}, \mathrm{kg} / \mathrm{m}^{2} \\
\quad(18.5-24.9)\end{array}$ & 1.0 & 1.0 & 1.0 & & 1.0 & 1.0 & 1.0 & 1.0 \\
\hline$<18.5$ & $\begin{array}{l}1.30(1.26 \\
1.34)_{1}<.0001\end{array}$ & $\begin{array}{l}1.54(1.44 \\
1.64),<.0001\end{array}$ & $\begin{array}{l}1.45(1.19 \\
1.76), 0.0002\end{array}$ & $\square$ & $\begin{array}{l}1.43(1.22, \\
1.66),<.0001\end{array}$ & $\begin{array}{l}1.22(1.18 \\
1.26),<.0001\end{array}$ & $\begin{array}{l}1.24(1.18 \\
1.30),<.0001\end{array}$ & $\begin{array}{l}1.36(1.31,1.42) \\
<.0001\end{array}$ \\
\hline$\geq 25.0$ & $\begin{array}{l}0.70(0.67 \\
0.73),<.0001\end{array}$ & $\begin{array}{l}0.68(0.59 \\
0.78),<.0001\end{array}$ & $\begin{array}{l}0.57(0.51 \\
0.64),<.0001\end{array}$ & $\square$ & $\begin{array}{l}0.68(0.65 \\
0.72),<.0001\end{array}$ & $\begin{array}{l}0.80(0.74 \\
0.87),<.0001\end{array}$ & $\begin{array}{l}0.77(0.69 \\
0.86)<.0001\end{array}$ & $\begin{array}{l}0.70(0.64,0.76) \\
\quad<.0001\end{array}$ \\
\hline $\begin{array}{l}\text { Hemoglobin } \\
\quad(\geq 11 \mathrm{~g} / \mathrm{dL})\end{array}$ & 1.0 & & & & & 1.0 & 1.0 & \\
\hline $\begin{array}{l}10.0-10.9 \mathrm{~g} / \\
\mathrm{dL} \text { (mild) }\end{array}$ & $\begin{array}{l}1.02(0.98 \\
1.06), 0.2489\end{array}$ & 塹 & $\underline{1}$ & $\underline{12}$ & 玨 & $\begin{array}{l}1.00(0.96 \\
1.05), 0.9940\end{array}$ & $\begin{array}{l}1.07(1.01 \\
1.13), 0.0187\end{array}$ & 诖 \\
\hline $\begin{array}{l}<10.0 \mathrm{~g} / \mathrm{dL} \\
\text { (moderate/ } \\
\text { severe) }\end{array}$ & $\begin{array}{l}1.12(1.08 \\
1.17),<.0001\end{array}$ & 軖 & $\underline{E}$ & $\underline{1 .}$ & 塹 & $\begin{array}{l}1.08 \\
(1.03,1.14) \\
0.0035\end{array}$ & $\begin{array}{l}1.20(1.14 \\
1.26),<.0001\end{array}$ & $\underline{\underline{E}}$ \\
\hline $\begin{array}{l}\text { Sex of the } \\
\text { baby (male) }\end{array}$ & 1.0 & 1.0 & 1.0 & 1.0 & 1.0 & 1.0 & 1.0 & 1.0 \\
\hline Female & $\begin{array}{l}1.19(1.17 \\
1.21),<.0001\end{array}$ & $\begin{array}{l}1.24(1.16 \\
1.31),<.0001\end{array}$ & $\begin{array}{l}1.19(1.09 \\
1.30),<.0001\end{array}$ & $\begin{array}{l}1.15(1.01 \\
1.31), 0.0296\end{array}$ & $\begin{array}{l}1.24(1.19 \\
1.28),<.0001\end{array}$ & $\begin{array}{l}1.16(1.11 \\
1.21),<.0001\end{array}$ & $\begin{array}{l}1.20(1.16 \\
1.24),<.0001\end{array}$ & $\begin{array}{l}1.17(1.12,1.23) \\
<.0001\end{array}$ \\
\hline
\end{tabular}

-BMI not calculated for Kenya because maternal height was not recorded before 2017

-Maternal hemoglobin not consistently collected at all GN sites except Belagavi, India and Nagpur, India

Generalized linear models were used to evaluate the relationship of potential factors and LBW and to develop point and interval estimates of relative risk associated with these factors. Generalized estimating equations were used to account for the correlation of outcomes within cluster to develop appropriate confidence intervals. The reference group is indicated by 1.0 in the Risk Ratio column

Another interesting observation from this study was the association of gender of the newborn with preterm birth and LBW. In African sites, female newborns were more likely to be preterm. Although reported previously the reasons for this finding are unclear [42, 43]. At all sites, the rate of LBW in female newborns was more than in males.

The strengths of our study are that it is a populationbased assessment of the burden of preterm birth and LBW across different LMIC community sites and their risk factors that differ by site indicating that further exploration of association of these risk factors may help to tailor public health strategies. The GN uses uniform and rigorous criteria across sites for assessment of gestational age, increasingly based on ultrasound dating (particularly first trimester) to improve precision of estimates of preterm birth rates. The GN has also focused on accurate estimation of measured birth weight within 6 days of birth in approximately $99 \%$ of neonates, to avoid rounding errors and delayed reporting of birth weight [15]. Missing values of key variables including birthweight are minimal, particularly as a result of increased institutional deliveries.

Limitations of the study include the population under study - it is not countrywide, because it is based on access to a rural and semi-urban population. Another limitation is that while estimation of gestational age 
Table 4 Maternal, delivery and infant characteristics as risk factors for preterm birth and low birth weight-overall and site specific risk ratios with $95 \%$ confidence intervals and $p$ values

\begin{tabular}{|c|c|c|c|c|c|c|c|c|}
\hline \multirow[t]{2}{*}{ Characteristic } & \multicolumn{8}{|c|}{ Relative risk $(95 \% \mathrm{Cl})$, p-value } \\
\hline & Overall, all sites & DRC & Zambia & Kenya & Guatemala & Belagavi & Nagpur & Pakistan \\
\hline $\begin{array}{l}\text { Maternal age } \\
(20-35)\end{array}$ & 1.0 & 1.0 & 1.0 & 1.0 & 1.0 & 1.0 & 1.0 & 1.0 \\
\hline$<20$ & $\begin{array}{l}1.41(1.32 \\
1.49),<.0001\end{array}$ & $\begin{array}{l}1.94(1.61,2.33) \\
\quad<.0001\end{array}$ & $\begin{array}{l}1.68(1.48,1.90) \\
<.0001\end{array}$ & $\begin{array}{l}2.38(2.08,2.72) \\
\quad<.0001\end{array}$ & $\begin{array}{l}1.32(1.22,1.42) \\
\quad<.0001\end{array}$ & $\begin{array}{l}1.16(1.06,1.28) \\
0.0024\end{array}$ & $\begin{array}{l}1.35(1.11,1.65) \\
0.0026\end{array}$ & $\begin{array}{l}1.30(1.15,1.48) \\
<.0001\end{array}$ \\
\hline$>35$ & $\begin{array}{l}1.08(1.00,1.17) \\
0.0385\end{array}$ & $\begin{array}{l}1.23(1.02,1.48) \\
0.0305\end{array}$ & $\begin{array}{l}1.10(0.89,1.35) \\
0.3785\end{array}$ & $\begin{array}{l}0.46(0.19,1.07) \\
0.0724\end{array}$ & $\begin{array}{l}1.19(1.05,1.35) \\
0.0057\end{array}$ & $\begin{array}{l}2.18(1.48,3.22) \\
\quad<.0001\end{array}$ & $\begin{array}{l}1.35(0.87,2.10) \\
0.1758\end{array}$ & $\begin{array}{l}0.91(0.78,1.07) \\
0.2510\end{array}$ \\
\hline $\begin{array}{l}\text { Maternal educa- } \\
\text { tion (University } \\
+ \text { +) }\end{array}$ & 1.0 & 1.0 & 1.0 & 1.0 & 1.0 & 1.0 & 1.0 & 1.0 \\
\hline $\begin{array}{l}\text { No formal } \\
\text { education }\end{array}$ & $\begin{array}{l}1.28(1.18 \\
1.38),<.0001\end{array}$ & & $\begin{array}{l}0.67(0.54,0.83) \\
0.0002\end{array}$ & $\begin{array}{l}0.95(0.49,1.82) \\
0.8741\end{array}$ & $\begin{array}{l}1.08(0.89,1.30) \\
0.4399\end{array}$ & $\begin{array}{l}1.26(1.10,1.45) \\
0.0008\end{array}$ & $\begin{array}{l}1.32(1.06,1.65) \\
0.0140\end{array}$ & $\begin{array}{l}1.25(1.04,1.50) \\
0.0165\end{array}$ \\
\hline $\begin{array}{l}\text { Primary/sec- } \\
\text { ondary }\end{array}$ & $\begin{array}{l}1.13(1.06,1.21) \\
0.0002\end{array}$ & & $\begin{array}{l}0.78(0.64,0.96) \\
0.0201\end{array}$ & $\begin{array}{l}0.93(0.64,1.35) \\
0.6876\end{array}$ & $\begin{array}{l}1.11(0.96,1.27) \\
0.1620\end{array}$ & $\begin{array}{l}0.98(0.88,1.08) \\
0.6455\end{array}$ & $\begin{array}{l}1.39(1.23,1.57) \\
<.0001\end{array}$ & $\begin{array}{l}1.07(0.87,1.32), \\
0.5037\end{array}$ \\
\hline Parity (1-2) & 1.0 & 1.0 & 1.0 & 1.0 & 1.0 & 1.0 & 1.0 & 1.0 \\
\hline 0 & $\begin{array}{l}1.27(1.21 \\
1.33),<.0001\end{array}$ & $\begin{array}{l}1.95(1.69,2.25) \\
<.0001\end{array}$ & $\begin{array}{l}1.46(1.36,1.57) \\
<.0001\end{array}$ & $\begin{array}{l}2.14(1.79,2.57) \\
\quad<.0001\end{array}$ & $\begin{array}{l}1.14(1.03,1.27) \\
0.0122\end{array}$ & $\begin{array}{l}1.22(1.08,1.39) \\
0.0014\end{array}$ & $\begin{array}{l}1.26(1.16,1.36) \\
<.0001\end{array}$ & $\begin{array}{l}1.12(1.05,1.20), \\
0.0010\end{array}$ \\
\hline$>2$ & $\begin{array}{l}0.90(0.86 \\
0.95),<.0001\end{array}$ & $\begin{array}{l}0.92(0.84,1.01) \\
0.0822\end{array}$ & $\begin{array}{l}0.90(0.80,1.03) \\
0.1159\end{array}$ & $\begin{array}{l}0.69(0.58,0.82) \\
\quad<.0001\end{array}$ & $\begin{array}{l}0.99(0.87,1.12) \\
0.8555\end{array}$ & $\begin{array}{l}1.08(0.99,1.18) \\
0.0977\end{array}$ & $\begin{array}{l}1.43(1.03,1.99) \\
0.0349\end{array}$ & $\begin{array}{l}0.85(0.79,0.91) \\
\quad<.0001\end{array}$ \\
\hline $\begin{array}{l}\text { Consumption } \\
\text { of vitamins/ } \\
\text { calcium/iron }\end{array}$ & 1.0 & 1.0 & 1.0 & 1.0 & 1.0 & 1.0 & 1.0 & 1.0 \\
\hline Not consumed & $\begin{array}{l}1.30(1.15 \\
1.47),<.0001\end{array}$ & $\begin{array}{l}1.82(1.44,2.31) \\
\quad<.0001\end{array}$ & $\begin{array}{l}2.94(0.89,9.77) \\
0.0783\end{array}$ & $\begin{array}{l}1.90(0.91,3.95) \\
0.0875\end{array}$ & $\begin{array}{l}1.22(1.03,1.45) \\
0.0227\end{array}$ & $\begin{array}{l}2.17(1.91,2.46) \\
\quad<.0001\end{array}$ & $\begin{array}{l}0.72(0.29,1.75) \\
0.4654\end{array}$ & $\begin{array}{l}1.08(1.01,1.16), \\
0.0357\end{array}$ \\
\hline $\begin{array}{l}\text { Received tetanus } \\
\text { toxoid immu- } \\
\text { nization }\end{array}$ & 1.0 & 1.0 & 1.0 & 1.0 & 1.0 & 1.0 & 1.0 & 1.0 \\
\hline Did not receive & $\begin{array}{l}1.13(1.04,1.23) \\
0.0030\end{array}$ & $\begin{array}{l}1.39(1.03,1.86) \\
0.0294\end{array}$ & $\begin{array}{l}0.67(0.43,1.05) \\
0.0806\end{array}$ & $\begin{array}{l}0.75(0.48,1.16) \\
0.1939\end{array}$ & $\begin{array}{l}0.92(0.84,1.01) \\
0.0664\end{array}$ & $\begin{array}{l}0.57(0.09,3.54) \\
0.5503\end{array}$ & $\begin{array}{l}1.15(0.56,2.39) \\
0.7008\end{array}$ & $\begin{array}{l}1.23(1.14,1.33), \\
<.0001\end{array}$ \\
\hline $\begin{array}{l}\text { Number of ANC } \\
\text { visits }(4+)\end{array}$ & 1.0 & 1.0 & 1.0 & 1.0 & 1.0 & 1.0 & 1.0 & 1.0 \\
\hline 0 & $\begin{array}{l}1.88(1.56 \\
2.27),<.0001\end{array}$ & $\begin{array}{l}5.27(3.76,7.39) \\
\quad<.0001\end{array}$ & $\begin{array}{l}15.00(6.23 \\
36.10),<.0001\end{array}$ & $\begin{array}{l}5.93(4.06 \\
8.68),<.0001\end{array}$ & $\begin{array}{l}1.29(1.03,1.60) \\
0.0257\end{array}$ & $\begin{array}{l}3.14(1.15,8.54) \\
0.0252\end{array}$ & $\begin{array}{l}0.35(0.14,0.87) \\
0.0234\end{array}$ & $\begin{array}{l}1.32(1.12,1.55), \\
0.0007\end{array}$ \\
\hline $1-3$ & $\begin{array}{l}1.68(1.55 \\
1.83),<.0001\end{array}$ & $\begin{array}{l}3.17(2.57,3.91) \\
\quad<.0001\end{array}$ & $\begin{array}{l}3.00(2.22,4.06) \\
\quad<.0001\end{array}$ & $\begin{array}{l}2.62(2.09,3.29) \\
\quad<.0001\end{array}$ & $\begin{array}{l}1.59(1.47,1.72) \\
<.0001\end{array}$ & $\begin{array}{l}2.13(1.87,2.44) \\
\quad<.0001\end{array}$ & $\begin{array}{l}1.40(1.12,1.75) \\
0.0030\end{array}$ & $\begin{array}{l}1.16(1.09 \\
1.24),<.0001\end{array}$ \\
\hline $\begin{array}{l}\text { No obstructive } \\
\text { labor }\end{array}$ & 1.0 & 1.0 & 1.0 & 1.0 & 1.0 & 1.0 & 1.0 & 1.0 \\
\hline $\begin{array}{c}\text { Had obstruc- } \\
\text { tive labor }\end{array}$ & $\begin{array}{l}0.78(0.70 \\
0.87),<.0001\end{array}$ & $\begin{array}{l}1.51(1.20,1.89) \\
0.0004\end{array}$ & $\begin{array}{l}1.28(0.84,1.97) \\
0.2551\end{array}$ & $\begin{array}{l}1.71(1.19,2.44) \\
0.0036\end{array}$ & $\begin{array}{l}0.59(0.43,0.82) \\
0.0018\end{array}$ & $\begin{array}{l}0.76(0.59,0.97) \\
0.0251\end{array}$ & $\begin{array}{l}0.68(0.56,0.84) \\
0.0002\end{array}$ & $\begin{array}{l}0.79(0.71 \\
0.88),<.0001\end{array}$ \\
\hline $\begin{array}{l}\text { No severe } \\
\text { antepartum } \\
\text { hemorrhage }\end{array}$ & 1.0 & 1.0 & 1.0 & 1.0 & 1.0 & 1.0 & 1.0 & 1.0 \\
\hline $\begin{array}{l}\text { Had severe } \\
\text { antepartum } \\
\text { hemorrhage }\end{array}$ & $\begin{array}{l}5.18(4.44 \\
6.04),<.0001\end{array}$ & $\begin{array}{l}6.63(5.04 \\
8.72),<.0001\end{array}$ & $\begin{array}{l}10.24(7.15 \\
14.66)<.0001\end{array}$ & $\begin{array}{l}10.28(6.29 \\
16.77),<.0001\end{array}$ & $\begin{array}{l}8.52(6.99 \\
10.40),<.0001\end{array}$ & $\begin{array}{l}7.40(6.22,8.81) \\
\quad<.0001\end{array}$ & $\begin{array}{l}8.00(6.16,10.38) \\
\quad<.0001\end{array}$ & $\begin{array}{l}2.75(2.44,3.11) \\
\quad<.0001\end{array}$ \\
\hline $\begin{array}{l}\text { No severe } \\
\text { postpartum } \\
\text { hemorrhage }\end{array}$ & 1.0 & 1.0 & 1.0 & 1.0 & 1.0 & 1.0 & 1.0 & 1.0 \\
\hline $\begin{array}{l}\text { Had severe } \\
\text { postpartum } \\
\text { hemorrhage }\end{array}$ & $\begin{array}{l}1.22(1.07,1.40) \\
0.0035\end{array}$ & $\begin{array}{l}1.10(0.68,1.77) \\
0.6996\end{array}$ & $\begin{array}{l}1.67(1.16,2.42) \\
0.0062\end{array}$ & $\begin{array}{l}3.42(2.14,5.46) \\
\quad<.0001\end{array}$ & $\begin{array}{l}1.80(1.31,2.49) \\
0.0003\end{array}$ & $\begin{array}{l}1.18(0.97,1.43) \\
0.0980\end{array}$ & $\begin{array}{l}1.70(0.90,3.20) \\
0.0996\end{array}$ & $\begin{array}{l}0.96(0.85,1.09) \\
0.5243\end{array}$ \\
\hline $\begin{array}{l}\text { No hypertensive } \\
\text { disorders }\end{array}$ & 1.0 & 1.0 & 1.0 & 1.0 & 1.0 & 1.0 & 1.0 & 1.0 \\
\hline $\begin{array}{l}\text { Had hyperten- } \\
\text { sive disorders }\end{array}$ & $\begin{array}{l}2.74(2.48 \\
3.02),<.0001\end{array}$ & $\begin{array}{l}2.64(1.17,5.96) \\
0.0193\end{array}$ & $\begin{array}{l}4.54(2.82 \\
7.31),<.0001\end{array}$ & $\begin{array}{l}10.72(5.60 \\
20.51),<.0001\end{array}$ & $\begin{array}{l}2.84(2.52 \\
3.19),<.0001\end{array}$ & $\begin{array}{l}3.09(2.77 \\
3.44),<.0001\end{array}$ & $\begin{array}{l}3.18(2.80 \\
3.61),<.0001\end{array}$ & $\begin{array}{l}1.46(1.25 \\
1.72),<.0001\end{array}$ \\
\hline $\begin{array}{l}\text { No fetal malpre- } \\
\text { sentation }\end{array}$ & 1.0 & 1.0 & 1.0 & 1.0 & 1.0 & 1.0 & 1.0 & 1.0 \\
\hline $\begin{array}{l}\text { Had fetal } \\
\text { malpresenta- } \\
\text { tion }\end{array}$ & $\begin{array}{l}1.74(1.56 \\
1.93),<.0001\end{array}$ & $\begin{array}{l}2.93(1.68,5.13) \\
0.0002\end{array}$ & $\begin{array}{l}2.62(1.58,4.35) \\
0.0002\end{array}$ & $\begin{array}{l}3.50(1.90 \\
6.47),<.0001\end{array}$ & $\begin{array}{l}1.80(1.48 \\
2.19),<.0001\end{array}$ & $\begin{array}{l}1.83(1.42 \\
2.35),<.0001\end{array}$ & $\begin{array}{l}1.17(0.92,1.50) \\
0.1985\end{array}$ & $\begin{array}{l}1.57(1.38 \\
1.78),<.0001\end{array}$ \\
\hline
\end{tabular}


Table 4 (continued)

\begin{tabular}{|c|c|c|c|c|c|c|c|c|}
\hline \multirow[t]{2}{*}{ Characteristic } & \multicolumn{8}{|c|}{ Relative risk $(95 \% \mathrm{Cl}), \mathrm{p}$-value } \\
\hline & Overall, all sites & DRC & Zambia & Kenya & Guatemala & Belagavi & Nagpur & Pakistan \\
\hline $\begin{array}{l}\mathrm{BMI}, \mathrm{kg} / \mathrm{m}^{2} \\
\quad(18.5-24.9)\end{array}$ & 1.0 & 1.0 & 1.0 & & 1.0 & 1.0 & 1.0 & 1.0 \\
\hline$<18.5$ & $\begin{array}{l}1.33(1.27 \\
1.39),<.0001\end{array}$ & $\begin{array}{l}1.40(1.28 \\
1.53),<.0001\end{array}$ & $\begin{array}{l}1.39(1.20 \\
1.62),<.0001\end{array}$ & $\square$ & $\begin{array}{l}1.42(1.07,1.88) \\
0.0139\end{array}$ & $\begin{array}{l}1.26(1.16 \\
1.38),<.0001\end{array}$ & $\begin{array}{l}1.28(1.15 \\
1.42),<.0001\end{array}$ & $\begin{array}{l}1.40(1.31 \\
1.50),<.0001\end{array}$ \\
\hline$\geq 25.0$ & $\begin{array}{l}0.77(0.72,0.81) \\
\quad<.0001\end{array}$ & $\begin{array}{l}0.68(0.57 \\
0.80)_{,}<.0001\end{array}$ & $\begin{array}{l}0.61(0.54 \\
0.68),<.0001\end{array}$ & $\square$ & $\begin{array}{l}0.73(0.66 \\
0.81),<.0001\end{array}$ & $\begin{array}{l}1.12(0.95,1.33) \\
0.1603\end{array}$ & $\begin{array}{l}0.82(0.63,1.07) \\
\quad 0.1503\end{array}$ & $\begin{array}{l}0.76(0.69 \\
0.84),<.0001\end{array}$ \\
\hline $\begin{array}{l}\text { Hemoglobin } \\
\qquad(\geq 11 \mathrm{~g} / \mathrm{dL})\end{array}$ & 1.0 & & & & & 1.0 & 1.0 & \\
\hline $\begin{array}{l}10.0-10.9 \mathrm{~g} / \mathrm{dL} \\
\quad \text { (mild) }\end{array}$ & $\begin{array}{l}0.96(0.87,1.05) \\
\quad 0.3580\end{array}$ & 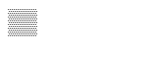 & $\overline{\underline{N}}$ & $\overline{=}$ & $\sum$ & $\begin{array}{l}0.93(0.82,1.05) \\
0.2182\end{array}$ & $\begin{array}{l}1.04(0.89,1.23) \\
0.6142\end{array}$ & $\underline{\underline{Z}}$ \\
\hline $\begin{array}{l}<10.0 \mathrm{~g} / \mathrm{dL} \\
\text { (moderate/ } \\
\text { severe) }\end{array}$ & $\begin{array}{l}1.12(1.02,1.23) \\
0.0137\end{array}$ & 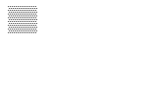 & \pm & 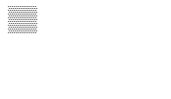 & $\underline{E}$ & $\begin{array}{l}1.08(0.97,1.21) \\
0.1754\end{array}$ & $\begin{array}{l}1.25(1.07,1.46) \\
0.0046\end{array}$ & \pm \\
\hline $\begin{array}{l}\text { Sex of the baby } \\
\text { (MALE) }\end{array}$ & 1.0 & 1.0 & 1.0 & 1.0 & 1.0 & 1.0 & 1.0 & 1.0 \\
\hline Female & $\begin{array}{l}1.01(0.98,1.04) \\
0.5527\end{array}$ & $\begin{array}{l}1.18(1.09, \\
1.28),<.0001\end{array}$ & $\begin{array}{l}1.13(1.08 \\
1.19)_{,}<.0001\end{array}$ & $\begin{array}{c}1.00(0.88,1.13) \\
0.9487\end{array}$ & $\begin{array}{l}0.94(0.88,0.99) \\
0.0236\end{array}$ & $\begin{array}{l}0.86(0.81 \\
0.92),<.0001\end{array}$ & $\begin{array}{c}1.00(0.94,1.07) \\
0.9333\end{array}$ & $\begin{array}{l}1.07(1.01,1.15) \\
0.0338\end{array}$ \\
\hline
\end{tabular}

-BMI not calculated for Kenya because maternal height was not recorded before 2017

-maternal hemoglobin not consistently collected at all GN sites except Belagavi, India and Nagpur, India

Generalized linear models were used to evaluate the relationship of potential factors and the combination of prematurity and LBW and to develop point and interval estimates of relative risk associated with these factors. Generalized estimating equations were used to account for the correlation of outcomes within cluster to develop appropriate confidence intervals. The reference group is indicated by 1.0 in the Risk Ratio column

and therefore preterm birth rates are improving, they are not yet optimal.

LMP may not be a reliable indicator in this population due to recall bias and inability to remember the exact LMP by less educated individuals. Even when the LMP is known, there is a risk for potential bias as the estimation of LMP is based on the assumption of a uniform 28-day cycle with ovulation on day 14 of that cycle, both of which may not necessarily be true, especially if contraceptives have been used before conception [44-46]. There can be a lack of agreement on the definition (women estimate the LMP as the last day of the menstrual period) of LMP between the doctor and pregnant woman. This can lead to errors and discrepancies in GA assessment by LMP [47]. Ultrasound dating is also limited by the changes in the size of the fetus which is not uniform throughout the pregnancy. It does not account for growth restriction and thus can lead to misclassification of term growth restricted baby as a preterm birth [48]. The magnitude and direction of the systematic bias should be considered while using the US based estimates. Increased access to high quality ultrasound estimates early in pregnancy is likely to further improve precision of preterm birth estimates. Improved precision of gestational age will allow estimation of growth restriction at all gestational ages (SGA). Rates of SGA and its determinants at each site were not estimated in this analysis. So further research is needed to understand the risk factors of SGA and how they differ at each site, when better estimates of gestational age become available.

Additionally, the association of plausible risk factors like socio-economic status, income, history or previous preterm as well as modifiable risk factors should be accounted for in the future research.

\section{Conclusion}

Rates of preterm births, LBWs and their combination remain high at the GN sites. Prominent risk factors that were similar across sites included nulliparity, maternal age under 20 years, less than 4 antenatal care visits, severe antenatal hemorrhage, and hypertensive disease.

While all pregnancies need care and consideration to prevent preterm births, the younger nulliparous women who may have received limited access to ANC services and so are at higher risk for preterm births need more attention to prevent prematurity and LBW.

\section{Abbreviations \\ ANC: Antenatal care; BMI: Body mass index; DRC: Democratic Republic of Congo; g/dL: Grams per deciliter; GEE: Generalized estimating equations; GLM: Generalized linear models; GN: Global network; LBW: Low birth weight; LMICs: Lower and middle income countries; LMP: Last menstrual period; MNHR: Maternal and Newborn Health Registry; NICHD's: National Institute for Child Health and Human Development's; RR: Risk ratios; RTI: Research Triangle Institute; SGA: Small for gestational age.}

\section{Acknowledgements}

We thank all the study staff involved in collection of the data analyzed in this work and all the women who participated in the study - their health, wellbeing, and successful pregnancy outcomes are the motivation for performing 
this work. We acknowledge the efforts of statisticians from the Lata Medical Research Foundation Ms. Preeti Kawadkar and Ms. Nilima Bansod for their help with developing the figures for the study.

\section{About thissupplement}

This article has been published as part of Reproductive Health, Volume 17 Supplement 3, 2020: Global Network MNH. The full contents of the supplement are available at https://reproductive-health-journal.biomedcentral.com/ articles/supplements/volume-17-supplement-3.

\section{Authors' contributions}

YVP, ABP and PLH conceived and designed the study, and developed the initial data collection tools specific to the preterm and LBW project; YVP developed the initial draft which was substantially improved by ABP and PLH. The manuscript was further edited with inputs from RLG, VT, EAL, MB and PLH. VRT conducted statistical analyses and provided inputs with TLN, and EMM. All the authors participated in the creation and maintenance of the MNHR. All authors read and approved the final manuscript.

\section{Funding}

Publication of this supplement is funded by Grants (U01 HD040477, U01HD040636, U10HD078437, U10HD076461, U10HD076465, U10HD076457, U10HD078439, U10HD078438, and U10HD076474) from the Eunice Kennedy Shriver National Institute of Child Health and Human Development.

\section{Availability of data and materials}

A minimal dataset for the findings described in the manuscript will be shared upon request for the same.

\section{Ethics approval and consent to participate}

The appropriate institutional review boards/ethics research committees of the participating institutions approved the MNHR study. Individual informed consent for study participation is requested and obtained from each study participant. A Data Monitoring Committee, appointed by the NICHD, oversees and reviews the study semi-annually.

\section{Competing interests}

The authors have no relationships to disclose that may be deemed to influence the objectivity of this paper and its review. The authors report no commercial associations, either directly or through immediate family, in areas such as expert testimony, consulting, honoraria, stock holdings, equity interest, ownership, patent-licensing situations or employment that might pose a conflict of interest to this analysis. Additionally, the authors have no conflicts such as personal relationships or academic competition to disclose. The findings presented in this paper represent the views of the named authors only, and not the views of their institutions or organizations.

\section{Author details}

${ }^{1}$ Lata Medical Research Foundation, Nagpur, India. ${ }^{2}$ Datta Meghe Institute of Medical Sciences, Wardha, India. ${ }^{3}$ RTI International, Durham, NC, USA. ${ }^{4}$ Instituto de Nutrición de Centroamérica y Panamá, Guatemala City, Guatemala. ${ }^{5}$ Department of Obstetrics and Gynecology, Columbia University School of Medicine, New York, NY, USA. ${ }^{6}$ KLE Academy Higher Education and Research J N Medical College, Belagavi, Karnataka, India. ${ }^{7}$ Aga Khan University, Karachi, Pakistan. ${ }^{8}$ Moi University School of Medicine, Eldoret, Kenya. ${ }^{9}$ University Teaching Hospital, Lusaka, Zambia. ${ }^{10}$ University of North Carolina at Chapel Hill, Chapel Hill, NC, USA. ${ }^{11}$ Indiana School of Medicine, University of Indiana, Indianapolis, IN, USA. ${ }^{12}$ University of Colorado School of Medicine, Denver, CO, USA. ${ }^{13}$ Thomas Jefferson University, Philadelphia, USA. ${ }^{14}$ University of Alabama at Birmingham, Birmingham, AL, USA. ${ }^{15}$ Eunice Kennedy Shriver National Institute of Child Health and Human Development, Bethesda, MD, USA. ${ }^{16}$ School of Public Health, Boston University, Boston, MA, USA.

Received: 23 October 2020 Accepted: 29 October 2020 Published: 17 December 2020

\section{References}

1. Report of the Secretary-General. Sustainable Development Goals Report. United Nations Sustainable Development (Cited Sept 7 2019). https:// www.un.org/sustainabledevelopment/progress-report/ Accessed $15 \mathrm{Ja}$ 2020.

2. $\mathrm{WHO} \mid$ Care of the preterm and low-birth-weight newborn. (Cited Aug 12 2019). https://www.who.int/maternal_child_adolescent/newborns/ prematurity/en/ Accessed 15 Jan 2020.

3. Katz J, Lee AC, Kozuki N, Lawn JE, Cousens S, Blencowe H, et al. Mortality risk in preterm and small-for-gestational-age infants in low-income and middle-income countries: a pooled country analysis. Lancet. 2013;382(9890):417-25.

4. Lee AC, Katz J, Blencowe H, Cousens S, Kozuki N, Vogel JP, et al. National and regional estimates of term and preterm babies born small for gestational age in 138 low-income and middle-income countries in 2010. Lancet Glob Health. 2013;1(1):e26-36.

5. Blencowe H, Cousens S, Chou D, Oestergaard M, Say L, Moller A-B, et al. Born too soon: The global epidemiology of 15 million preterm births. Reprod Health. 2013;10(Suppl 1):S2.

6. Liu L, Oza S, Hogan D, Chu Y, Perin J, Zhu J, et al. Global, regional, and national causes of under-5 mortality in 2000-15: an updated systematic analysis with implications for the Sustainable Development Goals. Lancet. 2016;388(10063):3027-35.

7. Sania A, Smith ER, Manji K, Duggan C, Masanja H, Kisenge R, et al. Neonatal and infant mortality risk associated with preterm and small for gestational age births in Tanzania: individual level pooled analysis using the intergrowth standard. J Pediatrics. 2018;192:66-72.

8. Chawanpaiboon S, Vogel JP, Moller A-B, Lumbiganon P, Petzold M, Hogan $D$, et al. Global, regional, and national estimates of levels of preterm birth in 2014: a systematic review and modelling analysis. Lancet Glob Health. 2019;7(1):e37-46.

9. Blencowe H, Krasevec J, de Onis M, Black RE, An X, Stevens GA, et al. National, regional, and worldwide estimates of low birthweight in 2015, with trends from 2000: a systematic analysis. Lancet Glob Health. 2019;7(7):e849-60.

10. Rüegger C, Hegglin M, Adams M, Bucher HU. Swiss Neonatal Network. Population based trends in mortality, morbidity and treatment for very preterm- and very low birth weight infants over 12 years. BMC Pediatr. 2012;12:17

11. Garcés A, MacGuire E, Franklin H, Alfaro N, Arroyo G, Figueroa L et al. Looking Beyond the numbers: quality assurance procedures in the global network for women's and children's health research Maternal Newborn Health Registry. BMC Supp; 2020

12. Goldenberg RL, Nathan RO, Swanson D, Saleem S, Mirza W, Esamai F, et al. Routine antenatal ultrasound in low- and middle-income countries: first look-a cluster randomised trial. BJOG. 2018;125(12):1591-9.

13. Hoffman MK, Goudar SS, Kodkany BS, Goco N, Koso-Thomas M, Miodovnik $M$, et al. A description of the methods of the aspirin supplementation for pregnancy indicated risk reduction in nulliparas (ASPIRIN) study. BMC Pregnancy Childbirth. 2017;17(1):135

14. Hambidge KM, Krebs NF, Westcott JE, Garces A, Goudar SS, Kodkany BS, et al. Preconception maternal nutrition: a multi-site randomized controlled trial. BMC Pregnancy Childbirth. 2014;14:111.

15. Goudar SS, Carlo WA, McClure EM, Pasha O, Patel A, Esamai F, et al. The Maternal and Newborn Health Registry Study of the Global Network for Women's and Children's Health Research. Int J Gynaecol Obstet. 2012;118(3):190-3.

16. Patel A, Prakash AA, Das PK, Gupta S, Pusdekar YV, Hibberd PL. Maternal anemiaandunderweight asdeterminants of pregnancy outcomes: cohort study ineastern rural Maharashtra,India. BMJ Open. 2018;8(8):e021623.

17. Parks S, Hoffman MK, Goudar SS, Patel A, Saleem S, Ali SA, et al. Maternal anaemia and maternal, fetal, and neonatal outcomes in a prospective cohort study in India and Pakistan. BJOG. 2019;126(6):737-43.

18. Patel AB, Prakash AA, Raynes-Greenow C, Pusdekar YV, Hibberd PL. Description of inter-institutional referrals afteradmission for labor and delivery: a prospective population based cohort study in rural Maharashtra, India. BMC Health Serv Res. 2017;17:360.

19. Page CM, Patel A, Hibberd PL. Does smoke from biomass fuel contribute to anemia in pregnant women in Nagpur, India? A cross-sectional study. PLOS ONE. 2015;10(5):e0127890. 
20. Preterm birth. (Cited Aug 16 2019). https://www.who.int/news-room/ fact-sheets/detail/preterm-birth Accessed 15 Jan 2020

21. Best practices_Weight Percentiles calculator. (Cited Sept 30 2019). https ://www.who.int/reproductivehealth/topics/best_practices/weight_perce ntiles_calculator.xls. Accessed 21 Jan 2020

22. Mikolajczyk RT, Zhang J, Betran AP, Souza JP, Mori R, Gülmezoglu AM, et al. A global reference for fetal-weight and birthweight percentiles. Lancet. 2011;377(9780):1855-61.

23. WHO | Making every baby count: audit and review of stillbirths and neonatal deaths. WHO. (Cited Aug 16 2019). http://www.who.int/mater nal_child_adolescent/documents/stillbirth-neonatal-death-review/en/ Accessed 15 Jan 2020

24. de Araújo BF, Zatti H, Madi JM, Coelho MB, Olmi FB, Canabarro CT. Analysis of neonatal morbidity and mortality in late-preterm newborn infants. $J$ Pediatr. 2012;88(3):259-66.

25. Purisch SE, Gyamfi-Bannerman C. Epidemiology of preterm birth. Semin Perinatol. 2017;41 (7):387-91.

26. Baig SA, Khan N, Baqai T, Fatima A, Karim SA, Aziz S. Preterm birth and its associated risk factors. A study at tertiary care hospitals of Karachi, Pakistan. J Pak Med Assoc. 2013:63(3):414-8.

27. Marchant T, Willey B, Katz J, Clarke S, Kariuki S, ter Kuile F, et al. Neonatal mortality risk associated with preterm birth in East Africa, adjusted by weight for gestational age: individual participant level meta-analysis. PLOS Med. 2012;9(8):e1001292.

28. Iyoke CA, Lawani LO, Ezugwu EC, Ilo KK, llechukwu GC, Asinobi IN. Maternal risk factors for singleton preterm births and survival at the University of Nigeria Teaching Hospital, Enugu, Nigeria. Niger J Clin Pract. 2015;18(6):744-50.

29. Van Der Linden EL, Browne JL, Vissers KM, Antwi E, Agyepong IA, Grobbee $D E$, et al. Maternal body mass index and adverse pregnancy outcomes: a Ghanaian cohort study. Obesity. 2016:24(1):215-22.

30. Althabe F, Thorsten V, Klein K, McClure EM, Hibberd PL, Goldenberg RL, et al. The Antenatal Corticosteroids Trial (ACT)'s explanations for neonatal mortality —a secondary analysis. Reprod Health. 2016;13(1):62.

31. Althabe F, Belizán JM, McClure EM, Hemingway-Foday J, Berrueta M, Mazzoni A, et al. A population-based, multifaceted strategy to implement antenatal corticosteroid treatment versus standard care for the reduction of neonatal mortality due to preterm birth in low-income and middle-income countries: the ACT cluster-randomised trial. Lancet. 2015:385(9968):629-39.

32. Papageorghiou AT, Ohuma EO, Altman DG, Todros T, Cheikh Ismail L, Lambert A, et al. International standards for fetal growth based on serial ultrasound measurements: the Fetal Growth Longitudinal Study of the INTERGROWTH-21st Project. Lancet. 2014;384(9946):869-79.

33. Villar J, Cheikh Ismail L, Victora CG, Ohuma EO, Bertino E, Altman DG, et al. International standards for newborn weight, length, and head circumference by gestational age and sex: the Newborn Cross-Sectional Study of the INTERGROWTH-21st Project. Lancet. 2014;384(9946):857-68.

34. Gebreslasie K. Preterm Birth and Associated Factors among Mothers Who Gave Birth in Gondar Town Health Institutions. Advances in Nursing. 2016 (cited 2019 Aug 16). https://www.hindawi.com/journals/anurs /2016/4703138/ Accessed 15 Jan 2020
35. Manasyan A, Saleem S, Koso-Thomas M, Althabe F, Pasha O, Chomba E, et al. Assessment of obstetric and neonatal health services in developing country health facilities. Am J Perinatol. 2013;30(9):787-94.

36. Short VL, Geller SE, Moore JL, McClure EM, Goudar SS, Dhaded SM, et al. The relationship between body mass index in pregnancy and adverse maternal, perinatal, and neonatal outcomes in Rural India and Pakistan. Am J Perinatol. 2018;35(9):844-51.

37. Bose CL, Bauserman M, Goldenberg RL, Goudar SS, McClure EM, Pasha $\mathrm{O}$, et al. The Global Network Maternal Newborn Health Registry: a multinational, community-based registry of pregnancy outcomes. Reprod Health. 2015;12(Suppl 2):S1.

38. Lam CM, Wong SF. Risk factors for preterm delivery in women with placenta praevia and antepartum haemorrhage: retrospective study. Hong Kong Med J. 2002;8(3):163-6.

39. Sekiguchi A, Nakai A, Kawabata I, Hayashi M, Takeshita T. Type and location of placenta previa affect preterm delivery risk related to antepartum hemorrhage. Int J Med Sci. 2013;10(12):1683-8.

40. Muchemi OM, Echoka E, Makokha A. Factors associated with low birth weight among neonates born at Olkalou District Hospital, Central Region, Kenya. Pan Afr Med J. 2015;20:108.

41. A.M AAM and D. Impact of maternal nutrition on birth weight of babies. 2014 (Cited 2019 Sep 7). http://www.biomedres.info/abstract/impact-ofmaternal-nutrition-on-birth-weight-of-babies-883.html

42. Mondal D, Galloway TS, Bailey TC, Mathews F. Elevated risk of stillbirth in males: systematic review and meta-analysis of more than 30 million births. BMC Med. 2014;12:220.

43. Zeitlin J, Saurel-Cubizolles M-J, De Mouzon J, Rivera L, Ancel P-Y, Blondel $B$, et al. Fetal sex and preterm birth: are males at greater risk? Hum Reprod. 2002;17(10):2762-8

44. Petersson K, Lindkvist M, Persson M, Conner P, Ahman A, Mogren I. Prenatal diagnosis in Sweden 2011 to 2013-a register-based study. BMC Pregnancy Childbirth. 2016;16:365.

45. Committee on Obstetric Practice, The American Institute of Ultrasound in Medicine, The Society for Maternal- Fetal Medicine. Committee Opinion No 700: Methods for estimating the due date. Obstet Gynecol. 2017;129:e150

46. Rolnik DL, Wright D, Poon LC, O'Gorman N, Syngelaki A, de Paco MC, et al. Aspirin versus placebo in pregnancies at high risk for preterm preeclampsia. N Engl J Med. 2017;377:613-22.

47. Kallen B, Finnstrom O, Nygren KG, Olausson PO. Maternal and fetal factors which affect fetometry: Use of in-vitro fertilization and birth register data. Eur J Obstet Gynecol Reprod Biol. 2013;170:372-6.

48. Harland KK, Saftlas AF, Wallis AB, Yankowitz J, Triche EW, Zimmerman MB. Correction of systematic bias in ultrasound dating in studies of small-forgestational-age birth: an example from the lowa health in pregnancy study. Am J Epidemiol. 2012;176:443-55.

\section{Publisher's Note}

Springer Nature remains neutral with regard to jurisdictional claims in published maps and institutional affiliations.

Ready to submit your research? Choose BMC and benefit from

- fast, convenient online submission

- thorough peer review by experienced researchers in your field

- rapid publication on acceptance

- support for research data, including large and complex data types

- gold Open Access which fosters wider collaboration and increased citations

- maximum visibility for your research: over $100 \mathrm{M}$ website views per year

At $\mathrm{BMC}$, research is always in progress.

Learn more biomedcentral.com/submissions 